\title{
A SAM-Based Model, Constructed from the SNA, to be Used for Studying the Distributional Impacts of Government Policies in Portugal
}

\author{
58 Pages . Posted: 14 Jul 2008
}

\section{Susana Santos}

ISEG (School of Economics and Management) of the University of Lisboa; UECE (Research Unit on Complexity and Economics) and DE (Department of Economics)

Date Written: May 30, 2008

\section{Suggested Citation:}

Santos, Susana, A SAM-Based Model, Constructed from the SNA, to be Used for Studying the Distributional Impacts of Government Policies in Portugal (May 30, 2008). Available at SSRN:

https://ssrn.com/abstract=1159389 or http://dx.doi.org/10.2139/ssrn.1159389 


\section{A SAM-based Model, constructed from the SNA, to be used for studying the distributional impacts of government policies in Portugal.}

Susana Santos

ISEG (School of Economics and Management)/TULisboa - Technical University of Lisbon;

UECE - Research Unit on Complexity and Economics and DE - Department of Economics

Rua Miguel Lupi, 20, 1249-078 Lisboa, Portugal

Tel.: +351213925953

Fax: +351213971196

E-mail: ssantos@iseg.utl.pt.

Key Words: Social Accounting Matrix; SAM-based Models; Income distribution.

JEL Classification: D58; E10; E01; E61.

(May 2008)

Presented to the EcoMod2008 - International Conference on Policy Modeling, held in Berlin, Germany, on 3 July 2008.

Financial support by FCG (Fundação Calouste Gulbenkian) and FCT (Fundação para a Ciência e a Tecnologia) - Multi-annual Funding Project. 


\begin{abstract}
An attempt will be made to study the impacts of government policies on the distribution of income, paying close attention to the corresponding response of the different macroeconomic aggregates and balances.

The Social Accounting Matrix (SAM) will be chosen as the working instrument. A numerical version of the SAM, constructed from the System of National Accounts (SNA), will serve as the basis for the construction of an algebraic version of the same matrix for Portugal.

This methodological choice was linked to the fact that, underlying the SAM, there are interrelated subsystems that, in the numerical version of the matrix, provide an analytical picture of the circular flow or general equilibrium interactions of the market economy, when studied during a particular accounting period. On the other hand, in the algebraic version of the SAM, it is possible to measure and quantify the economy-wide effects of changes in the particular nominal flows represented by the numerical version (injections from and leakages into the system), which might be the result of policy measures.

To this end, a computable (numerically solvable) general (economy-wide) equilibrium (macroeconomic balance) approach will be adopted.

A SAM-based model will be constructed in perfect consonance with the SNA, in which each cell is defined with a linear equation or system of equations, whose components are all the known and quantified transactions of that system, using the parameters of the numerical SAM that served as the basis for this model.

Scenarios will be defined and analysed from experiments carried out in relation to the distributional impact of government policies.
\end{abstract}




\section{CONTENTS}

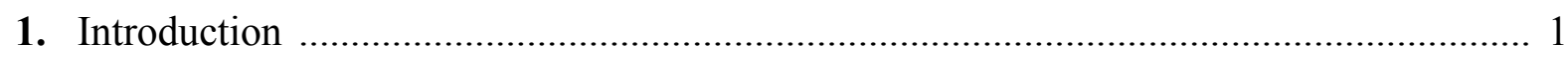

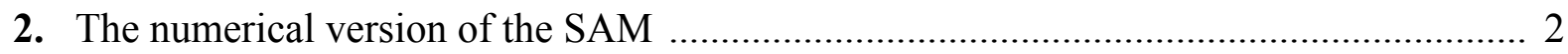

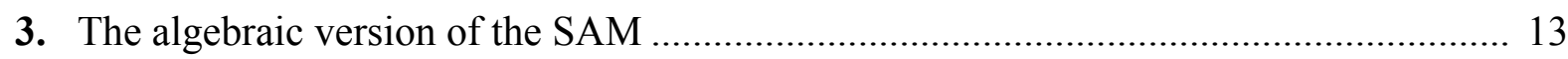

3.1. Framework and assumptions ...................................................................... 13

3.2. Specification by SAM blocks of sub-matrices ............................................... 14

3.2.1. Compensation of factors of production .............................................. 15

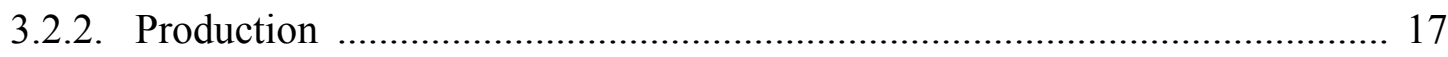

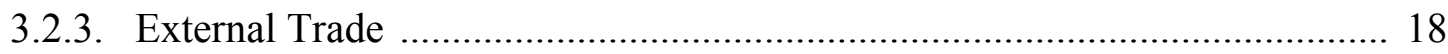

3.2.4. Net indirect taxes or net taxes on production and imports .......................... 18

3.2.5. Trade and Transport Margins .............................................................. 20

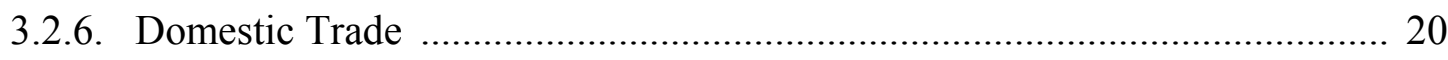

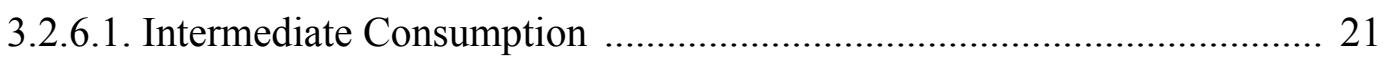

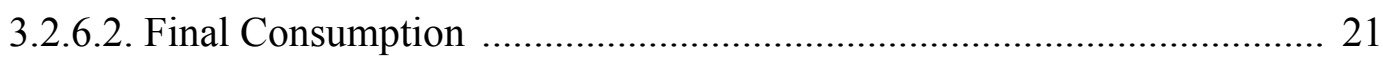

3.2.6.3. Gross Capital Formation .................................................................. 22

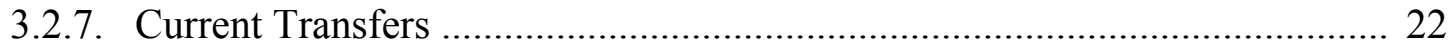

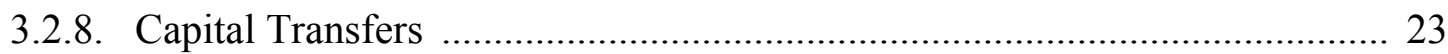

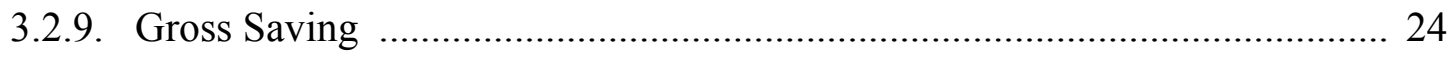

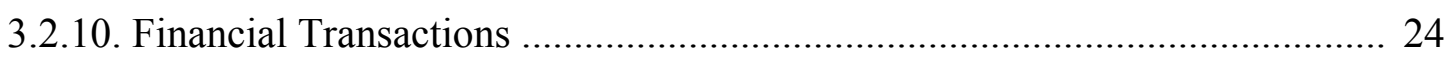

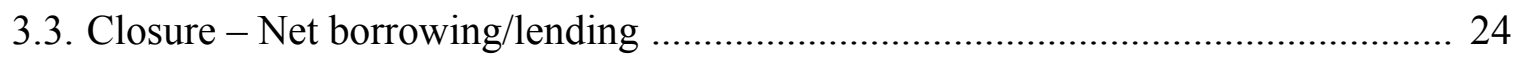

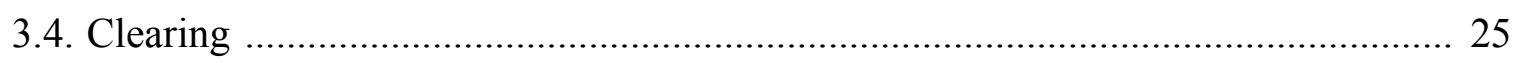

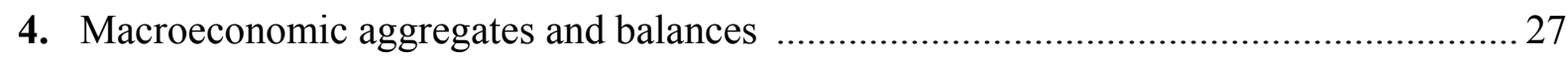

5. The structural indicators of the distribution and use of income .................................. 30

6. Experiments and scenarios with the distributional impact of government policies ........ 34

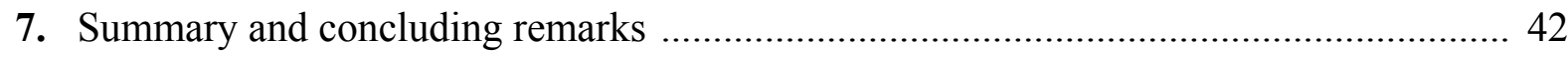

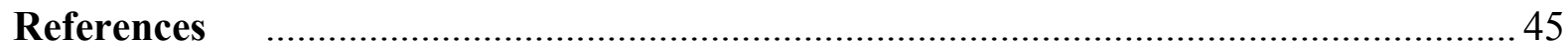

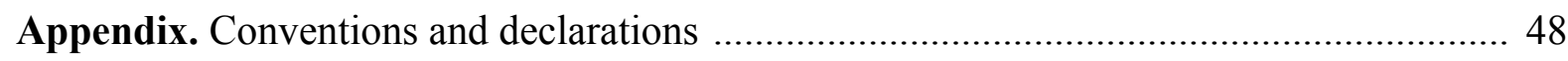




\section{Introduction}

The main purpose of this paper is to study the impacts of government policies on the distribution of income, paying close attention to the corresponding response of the different macroeconomic aggregates and balances.

Because of this aim, the author was obliged to work with data that were more than a decade out of date, since 1995 was the only year for which there existed workable data. However, the task to be carried out in this study is seen as an experiment that has never previously been undertaken for Portugal, while, furthermore, it seeks to demonstrate the importance and potentialities of the working instrument used.

The Social Accounting Matrix (SAM) is the working instrument, i.e. a square matrix in which, by convention, the entries made in rows represent resources, incomes, receipts or changes in assets, whilst the entries made in columns represent uses, outlays, expenditures or changes in liabilities and net worth. Therefore, for each row there is a corresponding column, with the totals of each of these being equal. These figures will include both production and institutional accounts, which are subdivided into yet other accounts.

A numerical version of the SAM, constructed from the System of National Accounts (SNA), will serve as the basis for the construction of an algebraic version of the same matrix.

This methodological choice was linked to the fact that, underlying the SAM, there are interrelated subsystems that, in the numerical version of the matrix, provide an analytical picture of the circular flow or the general equilibrium interactions of the market economy, when studied during a particular accounting period. On the other hand, in the algebraic version of the SAM, it is possible to measure and quantify the economy-wide effects of changes in the particular nominal flows represented by the numerical version (injections into and leakages from the system), which might be the result of policy measures.

Section 2 provides a rapid presentation of the numerical version of the SAM, constructed in perfect consonance with the System of National Accounts (SNA) through a top-down approach $^{1}$.

\footnotetext{
${ }^{1}$ A detailed presentation of this SAM was made to the EcoMod2006 - International Conference on Policy Modelling, held in Hong Kong, China, on 29 June 2006, under the title "Constructing a database for economic modelling from the System of National Accounts: a Social Accounting Matrix for Portugal". The paper presented at that conference is also published in the Working Paper Series of the Social Science Research Network (Santos S., 2006).
} 
In turn, Section 3 presents an algebraic version of the above-mentioned SAM, within a static short-term framework, adopting a computable (numerically solvable) general (economy-wide) equilibrium (macroeconomic balance) approach.

Like the numerical version, this algebraic version of the SAM, which will also be referred to as a SAM-based model, is constructed in perfect consonance with the SNA, with each cell being defined through a linear equation or system of equations, whose components are all the known and quantified transactions of that system. This model will be calibrated using parameters and exogenous variables calculated from the database, i.e. the numerical version of the SAM, presented in Section 2.

Sections 4 and 5 show how macroeconomic aggregates and balances, as well as the structural indicators of the distribution and use of income (which can be constructed from the available information), can be calculated from both versions of the SAM.

Section 6 defines and analyses scenarios arising from experiments that have been carried out into the distributional impact of government policies. For this purpose, some parameters and the exogenous variables used to calibrate the model will be subjected to shocks, the SAMbased model will then be processed and the impacts will be studied by considering the relative differences between the aggregates, balances and indicators presented in Sections 4 and 5, after and before the experiments.

Section 7 ends the paper with a summary and some concluding remarks designed to emphasise the importance of the SAM as a working instrument.

\section{The numerical version of the SAM}

The main purpose of this paper and the available information were the determinants of the classification adopted for the accounts of the numerical and, consequently, the algebraic versions of the SAM. Thus, in the case of the domestic economy, "Production" was divided into factors of production, activities and products, and "Institutions" into current, capital and financial accounts. Besides these accounts, we also have an aggregate account for the "rest of the world".

The criterion used by the author for ordering the accounts was the one underlying the basic SAM represented in Table 1.

Nowadays, the SNA in general and the Portuguese National Accounts in particular provide several (mutually exclusive) possibilities for the disaggregation of products and activities, 
only a few possibilities for the institutional accounts, and even fewer possibilities for the factors of production.

The SNA that has been used in Portugal since 1995 has been the European System of National and Regional Accounts in the European Community of 1995 - ESA 95 (Eurostat, 1996), which is based on the 1993 version of the International United Nations System of National Accounts - SNA 93, prepared by the Inter-Secretariat Working Group and published by the United Nations Statistical Office (ISWG, 1993).

Table 2 shows the Portuguese SAM that it was possible to construct from the SNA, with the particular purpose described in the introduction, and which will be broken down even further, albeit using other sources of information.

This macro-SAM was constructed from blocks of sub-matrices or sets of sub-matrices, whose transactions have common characteristics. These blocks can be specified through the identification of the transactions involved in the National Accounts, which is performed in Section 3 on the occasion of their formalisation. A systematised description of the sources of information and the method of calculation used is provided by Santos in "SAMs and SNA: An Application" (2005) and "Constructing a Database for Economic Modelling from the SNA: a SAM for Portugal" (2006). The first of these also includes a description of the SAM cell contents, although this relates to a SAM calculated for 1999.

As can be seen from its totals, Table 2, which represents the so-called macro-SAM, is a possible disaggregation of Table 1, which represents the so-called basic SAM (the completely aggregated macro-SAM).

If we look at the world around us, it is easy to agree with the statement that "the determinants of the distribution of income and the mechanisms by which it changes represent one of the most difficult theoretical and empirical problems facing the science of economics" (Dervis et al., 1982). If it were an easy task, then certainly the world today would be a fairer place.

Working on the empirical side, the author believes that "SAMs provide an invaluable statistical framework for the analysis of the mapping between the different kinds of distributions one may want to consider" (Dervis et al., 1982). 
Table 1. Portuguese basic SAM (Social Accounting Matrix) for 1995 (in millions of euros)

\begin{tabular}{|c|c|c|c|c|c|c|c|c|c|}
\hline \multirow{2}{*}{\multicolumn{2}{|c|}{$\begin{array}{r}\text { Outlays } \\
\text { Incomes } \\
\text { (receipts) }\end{array}$}} & \multicolumn{3}{|c|}{ Production and Trade } & \multicolumn{3}{|c|}{ Institutions } & \multirow{2}{*}{$\begin{array}{c}\text { Rest of the World } \\
\text { (RW) } \\
(7)\end{array}$} & \multirow[b]{2}{*}{ TOTAL } \\
\hline & & $\begin{array}{c}\text { Factors } \\
(1)\end{array}$ & $\begin{array}{l}\text { Activities } \\
\text { (2) }\end{array}$ & $\begin{array}{l}\text { Products } \\
\text { (3) }\end{array}$ & $\begin{array}{l}\text { Current A. } \\
\text { (4) }\end{array}$ & $\begin{array}{l}\text { Capital A. } \\
(5)\end{array}$ & $\begin{array}{c}\text { Financial A. } \\
(6)\end{array}$ & & \\
\hline \multirow{3}{*}{ 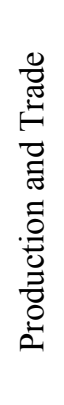 } & Factors (1) & 0 & $\begin{array}{c}\text { Gross Added } \\
\text { Value, at factor cost } \\
\quad(70725)\end{array}$ & 0 & 0 & 0 & 0 & $\begin{array}{c}\text { Compensation } \\
\text { of Factors from } \\
\text { the RW } \\
\left(\begin{array}{ll}3 & 243\end{array}\right) \\
\end{array}$ & $\begin{array}{l}\text { Aggregate } \\
\text { Factors } \\
\text { Income } \\
\text { (73 968) } \\
\end{array}$ \\
\hline & Activities (2) & 0 & 0 & $\begin{array}{l}\text { Production } \\
(154 \text { 394) }\end{array}$ & 0 & 0 & 0 & 0 & $\begin{array}{l}\text { Production } \\
\text { Value } \\
(154394) \\
\end{array}$ \\
\hline & Products (3) & 0 & $\begin{array}{c}\text { Intermediate } \\
\text { Consumption } \\
(84102) \\
\end{array}$ & $\begin{array}{c}\text { Trade and } \\
\text { Transport Margins } \\
(0)\end{array}$ & $\begin{array}{c}\text { Final } \\
\text { Consumption } \\
(64898) \\
\end{array}$ & $\begin{array}{l}\text { Gross Capital } \\
\text { Formation } \\
(19623) \\
\end{array}$ & 0 & $\begin{array}{l}\text { Exports } \\
(24433)\end{array}$ & $\begin{array}{l}\text { Aggregate } \\
\text { Demand } \\
(193056) \\
\end{array}$ \\
\hline \multirow{3}{*}{ : } & $\begin{array}{l}\text { Current A. } \\
\text { (4) }\end{array}$ & $\begin{array}{c}\text { Gross National } \\
\text { Income, at factor cost } \\
(70542)\end{array}$ & $\begin{array}{l}\text { Net taxes on } \\
\text { production } \\
\quad(-346)\end{array}$ & $\begin{array}{l}\text { Net taxes on } \\
\text { products } \\
(10283)\end{array}$ & $\begin{array}{l}\text { Current Transfers } \\
\text { (42 145) }\end{array}$ & 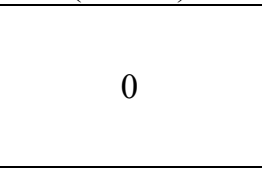 & 0 & $\begin{array}{c}\text { Current } \\
\text { Transfers from } \\
\text { the RW } \\
(3960) \\
\end{array}$ & $\begin{array}{l}\text { Aggregate } \\
\text { Income } \\
(126583)\end{array}$ \\
\hline & $\begin{array}{l}\text { Capital A. } \\
\text { (5) }\end{array}$ & 0 & 0 & 0 & $\begin{array}{l}\text { Gross Saving } \\
\quad(17291)\end{array}$ & $\begin{array}{c}\text { Capital Transfers } \\
(4930)\end{array}$ & $\begin{array}{l}\text { Net borrowing } \\
(40)\end{array}$ & $\begin{array}{l}\text { Capital } \\
\text { Transfers from } \\
\text { the RW } \\
(2320)\end{array}$ & $\begin{array}{l}\text { Investment } \\
\text { Funds } \\
(24582)\end{array}$ \\
\hline & $\begin{array}{r}\text { Financial A. } \\
\text { (6) }\end{array}$ & 0 & 0 & 0 & 0 & 0 & $\begin{array}{c}\text { Financial } \\
\text { Transactions } \\
(35030)\end{array}$ & $\begin{array}{c}\text { Financial } \\
\text { Transactions } \\
\text { from the RW } \\
(9257)\end{array}$ & $\begin{array}{c}\text { Total financial } \\
\text { transactions } \\
(44287)\end{array}$ \\
\hline \multicolumn{2}{|c|}{$\begin{array}{l}\text { Rest of the World } \\
\text { (RW) }\end{array}$} & $\begin{array}{l}\text { Compensation of } \\
\text { Factors to the RW } \\
\qquad(3426)\end{array}$ & $\begin{array}{l}\text { Net taxes on } \\
\text { production } \\
\quad(-87)\end{array}$ & $\begin{array}{c}\text { Imports } \\
+\begin{array}{c}\text { net taxes on } \\
\text { products }\end{array} \\
(28127+252) \\
\end{array}$ & $\begin{array}{l}\text { Current Transfers } \\
\text { to the RW } \\
(2249)\end{array}$ & $\begin{array}{c}\text { Capital Transfers } \\
\text { to the RW } \\
(29)\end{array}$ & $\begin{array}{c}\text { Financial } \\
\text { Transactions to } \\
\text { the RW } \\
(9217)\end{array}$ & & $\begin{array}{c}\text { Transactions } \\
\text { Value to the } \\
\text { RW } \\
(43213)\end{array}$ \\
\hline \multicolumn{2}{|c|}{ TOTAL } & $\begin{array}{l}\text { Aggregate Factors } \\
\text { Income } \\
(73968)\end{array}$ & $\begin{array}{c}\text { Total Costs } \\
(154394)\end{array}$ & $\begin{array}{l}\text { Aggregate } \\
\text { Supply } \\
(193056)\end{array}$ & $\begin{array}{l}\text { Aggregate } \\
\text { Income } \\
(126583)\end{array}$ & $\begin{array}{l}\text { Aggregate } \\
\text { Investment } \\
(24582)\end{array}$ & $\begin{array}{l}\text { Total financial } \\
\text { transactions } \\
\quad(44287)\end{array}$ & $\begin{array}{c}\text { Transactions } \\
\text { Value from the } \\
\text { RW } \\
(43213)\end{array}$ & \\
\hline
\end{tabular}

Source: Instituto Nacional de Estatística (Portuguese National Accounts for 1995) 
Table 2. Portuguese macro-SAM (Social Accounting Matrix) for 1995 (in millions of euros)

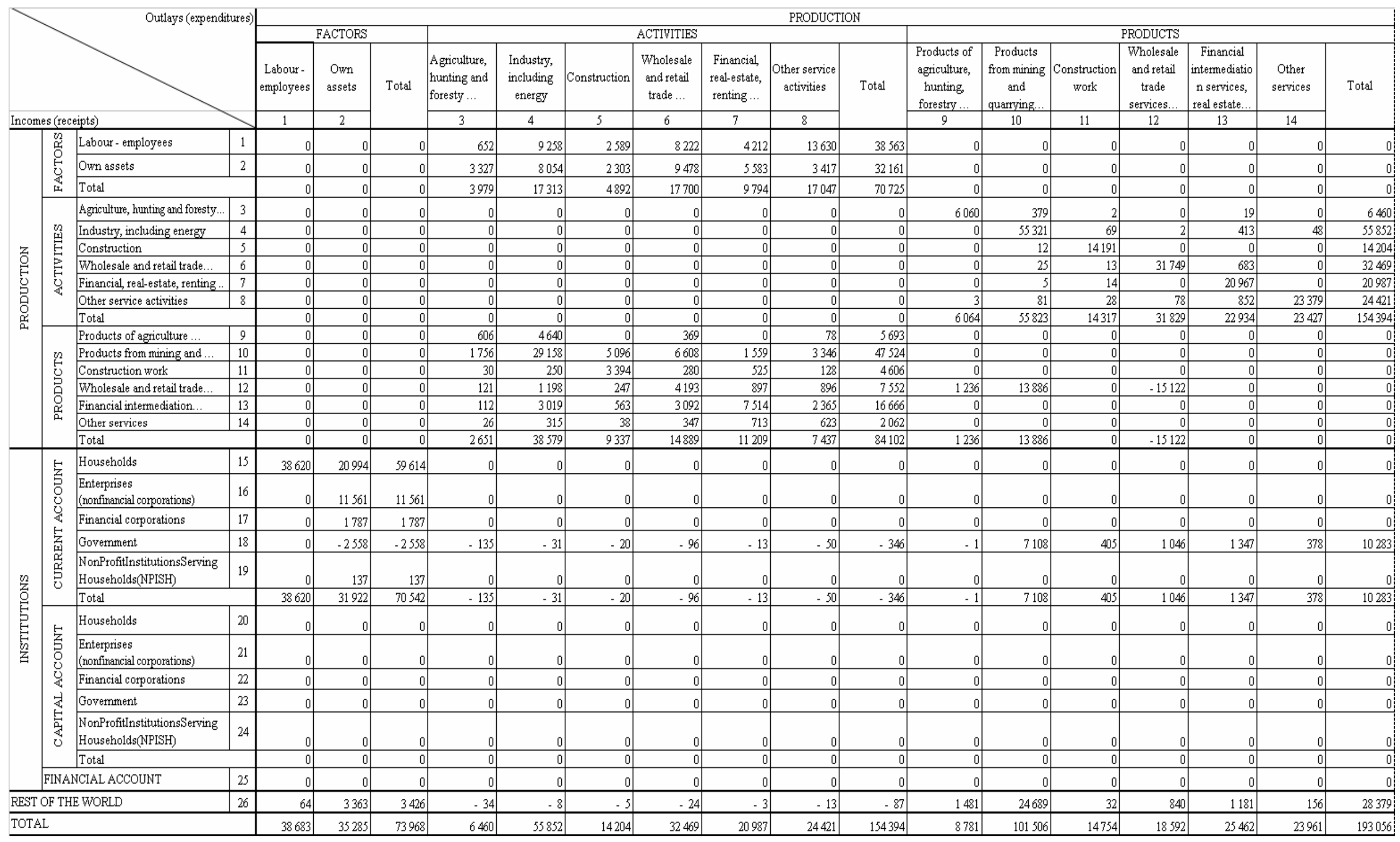

Source: Instituto Nacional de Estatística (Portuguese National Accounts for 1995) 
Table 2. Portuguese macro-SAM (Social Accounting Matrix) for 1995 (in millions of euros) (continued)

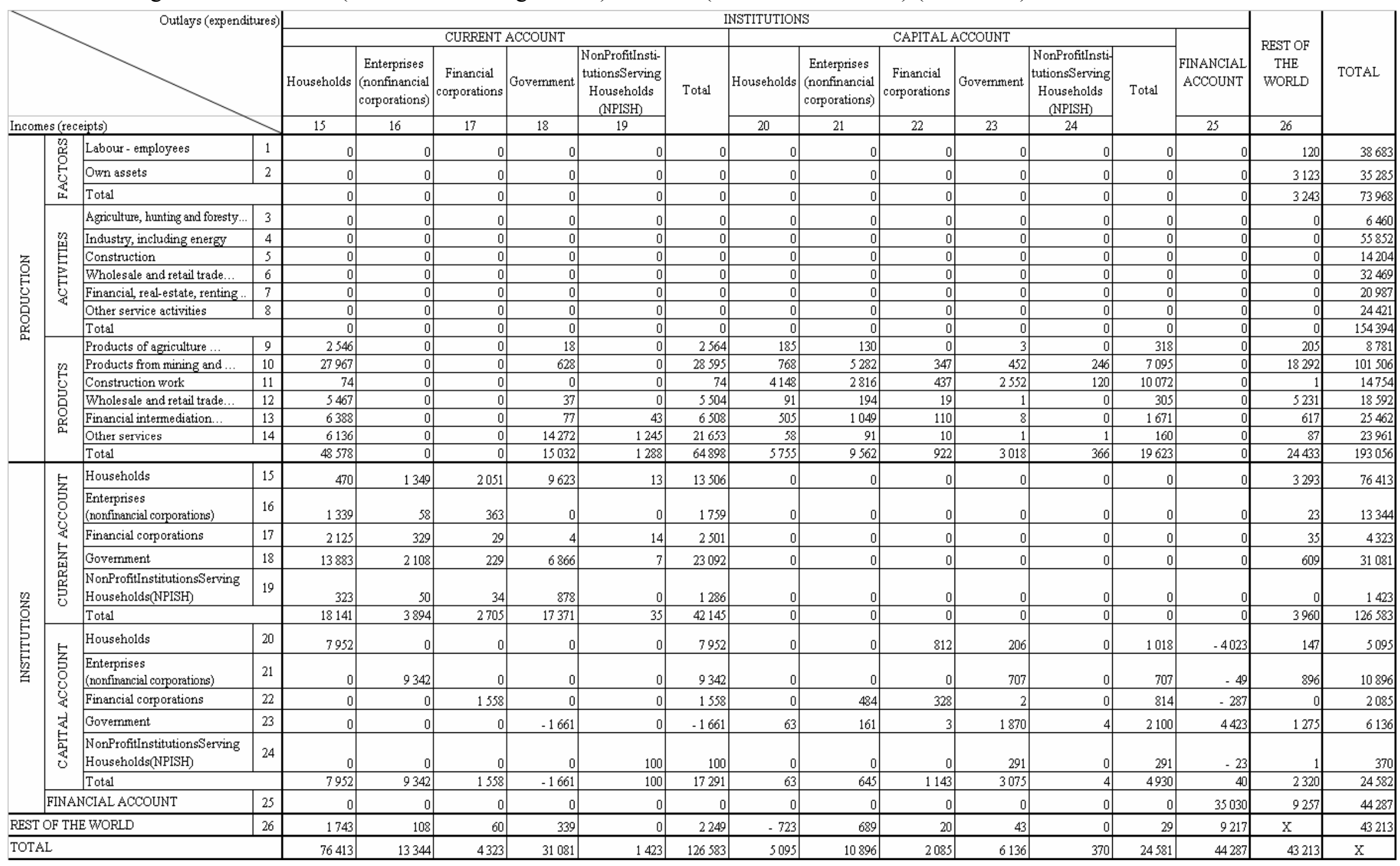

Source: Instituto Nacional de Estatística (Portuguese National Accounts for 1995) 
Perhaps in a rather simplistic way, but at least to begin with, the author accepts that the study of income distribution in a society involves the study of how the national pie is divided up and how it can then be sliced. The first aspect can be analysed from one or more snapshots of the economy, provided by a suitably disaggregated SAM, and the second from the modelling of that same SAM. Therefore, of crucial importance here is the way in which the primary and secondary distribution of income, as well as the use that is made of it, are dealt with. The factors of production account and the current account of the institutions are the accounts that cover such issues.

"In the SAM, the institution entitled 'households' really represents all the people in society" (Dervis et al., 1982). Its disaggregation therefore needs to be performed. On the other hand, the distribution of the (primary) incomes that accrue as a result of the involvement in processes of production or the ownership of assets among institutions (and activities) is covered by the factors of production account, so that its disaggregation must also be performed.

The question thus arises "how should these disaggregations be performed?" This will not, however, be discussed here, because our dependence on the available data is total ${ }^{2}$, although, despite the fact that the information is not up-to-date, it is nonetheless sufficient for us to be able to at least study some aspects of the distribution of income.

The workable data made available to the author for studying and modelling income distribution in Portugal consisted of an incomplete disaggregated National Accounting Matrix (NAM) and a previous (provisional) version for 1995, constructed as a result of the collaboration of the Portuguese Statistical Institute (Instituto Nacional de Estatística) in the work undertaken by the Leadership Group on Social Accounting Matrices, under the coordination of Statistics Netherlands (LEG, 2003).

In that NAM, labour was broken down into six types, according to the gender and education level of workers, and households were broken down into four types, according to their main source of income. Such disaggregation was performed using specific data sources, such as household budget surveys, the labour force survey and administrative data (employment records, income tax and social security files, etc. $)^{3}$.

In this paper, gender will not be considered and the factors of production will be disaggregated into two main groups: labour (or employees) and own assets; the latter being

\footnotetext{
${ }^{2}$ Dervis et al. (1982), for instance, discuss this aspect (see Chapter 12, Modelling Distributional Mechanisms).

${ }^{3}$ The document resulting from that work (LEG, 2003) highlights the limitations and the methodological details of such a valuable exercise.
} 
further disaggregated into labour (employers and own-account workers) and capital. This disaggregation was based on the data available in the National Accounts, since the primary distribution of income account does not distinguish own-account labour (employers and ownaccount workers) from capital.

In turn, households were disaggregated into the same four types.

Thus, one of the many advantages of the SAM approach could be referred to here, to use the words of Pyatt (1991): by "reducing the social accounts to the essential", the SAM approach "provides a useful starting point for understanding the assumptions and manipulations that have been built into the secondary source material which is typically employed by the majority of analysts".

This top-down approach made it possible to compile a numerical version of the SAM with 34 rows and 34 columns, which has the particularity of being balanced and perfectly consonant with the national accounts when aggregated at the level of 26 rows and columns - the case of the macro-SAM represented by Table 2. However the disaggregation into 34 rows and columns was also performed from credible sources, with its differences from the aggregated level (26 x 26) not being very significant, generally speaking.

If we consider $\mathrm{T}$ to be the matrix of the SAM transactions, represented by $t_{\mathrm{ij}}$, or a payment from column account $\mathrm{j}$ to row account $\mathrm{i}$, and $\mathrm{y}$ to be the vector of row sums, which equal the vector of column sums $\mathrm{x}$ :

and

$$
\begin{gathered}
y_{i}=\sum_{j} t_{i j} \\
x_{j}=\sum_{i} t_{i j}
\end{gathered}
$$

the $t_{i j}$ 's of the macro-SAM (26x26), with the factors of production and the current account of households completely aggregated and perfectly consonant with the national accounts and balanced (Table 2), can be considered as the "control" total of the $t_{i j}$ 's of the SAM (34x34).

Therefore the SAM will have sub-matrices that are disaggregations of cells (the "control" totals) of the macro-SAM, whose initial versions will be considered as $Z_{\mathrm{ij}}$, with typical element $\mathrm{z}_{\mathrm{ij}}$.

An adjusted SAM $\mathrm{T}^{\prime}{ }_{\mathrm{ij}}$ will be obtained from the adjustment of the sub-matrices $Z_{\mathrm{ij}}$. In order to do this, these sub-matrices will be adjusted one by one, using the RAS (Richard A. Stone) 
method, and an adjusted SAM $\mathrm{T}^{\prime}{ }_{\mathrm{ij}}$ will be obtained from the adjustment of the sub-matrices $\mathrm{Z}_{\mathrm{ij}}$.

Therefore, each element, derived from a sub-matrix $Z_{i j}$, of the adjusted matrix $T^{\prime}{ }_{i j}$ will be represented by the following equation:

$$
\begin{aligned}
\mathrm{t}^{\prime}{ }_{\mathrm{ij}} & =r_{\mathrm{i}} * \mathrm{z}_{\mathrm{ij}} * s_{\mathrm{j}} \\
\text { with, } r_{\mathrm{i}} & =\frac{\mathrm{c}_{\mathrm{i}}}{\sum_{\mathrm{j}} \mathrm{z}_{\mathrm{ij}}} \\
\text { and } \quad s_{\mathrm{j}} & =\frac{\mathrm{d}_{\mathrm{j}}}{\sum_{\mathrm{i}} \mathrm{z}_{\mathrm{ij}}}
\end{aligned}
$$

where: $\mathrm{t}^{\prime}{ }_{\mathrm{ij}}=$ (adjusted) SAM cell

$r_{\mathrm{i}}=$ row multiplier

$\mathrm{c}_{\mathrm{i}}=$ row control total

$\mathrm{Z}_{\mathrm{ij}}=$ typical element of the sub-matrix $\mathrm{Z}_{\mathrm{ij}}$

$s_{\mathrm{j}}=$ column multiplier

$\mathrm{d}_{\mathrm{j}}=$ column control total

$\mathrm{i}$ and $\mathrm{j}=$ disaggregations of the factors of production accounts and of the current account of households

As specified by Round (2003), this procedure results from the minimisation of

$$
\sum_{\mathrm{ij}} \mathrm{t}_{\mathrm{ij}} * \ln \left(\frac{\mathrm{t}_{\mathrm{ij}}}{\mathrm{z}_{\mathrm{ij}}}\right)
$$

subject to: $\sum_{\mathrm{j}} \mathrm{t}^{\prime}{ }_{\mathrm{ij}}=\mathrm{c}_{\mathrm{i}} ; \sum_{\mathrm{i}} \mathrm{t}^{\prime}{ }_{\mathrm{ij}}=\mathrm{d}_{\mathrm{j}} ; \mathrm{z}_{\mathrm{ij}}>0$.

The calculations were performed iteratively, with the sub-matrices $Z_{\mathrm{ij}}$ in the last iteration, in which $r_{\mathrm{i}}$ and $s_{\mathrm{j}}$ are equal to 1 , being the ones that are included in Table 3 - the numerical version, or the database, of the algebraic version, or the model, to be defined and worked with in the next section. 
Table 3. Portuguese SAM (Social Accounting Matrix) for 1995 (in millions of euros)

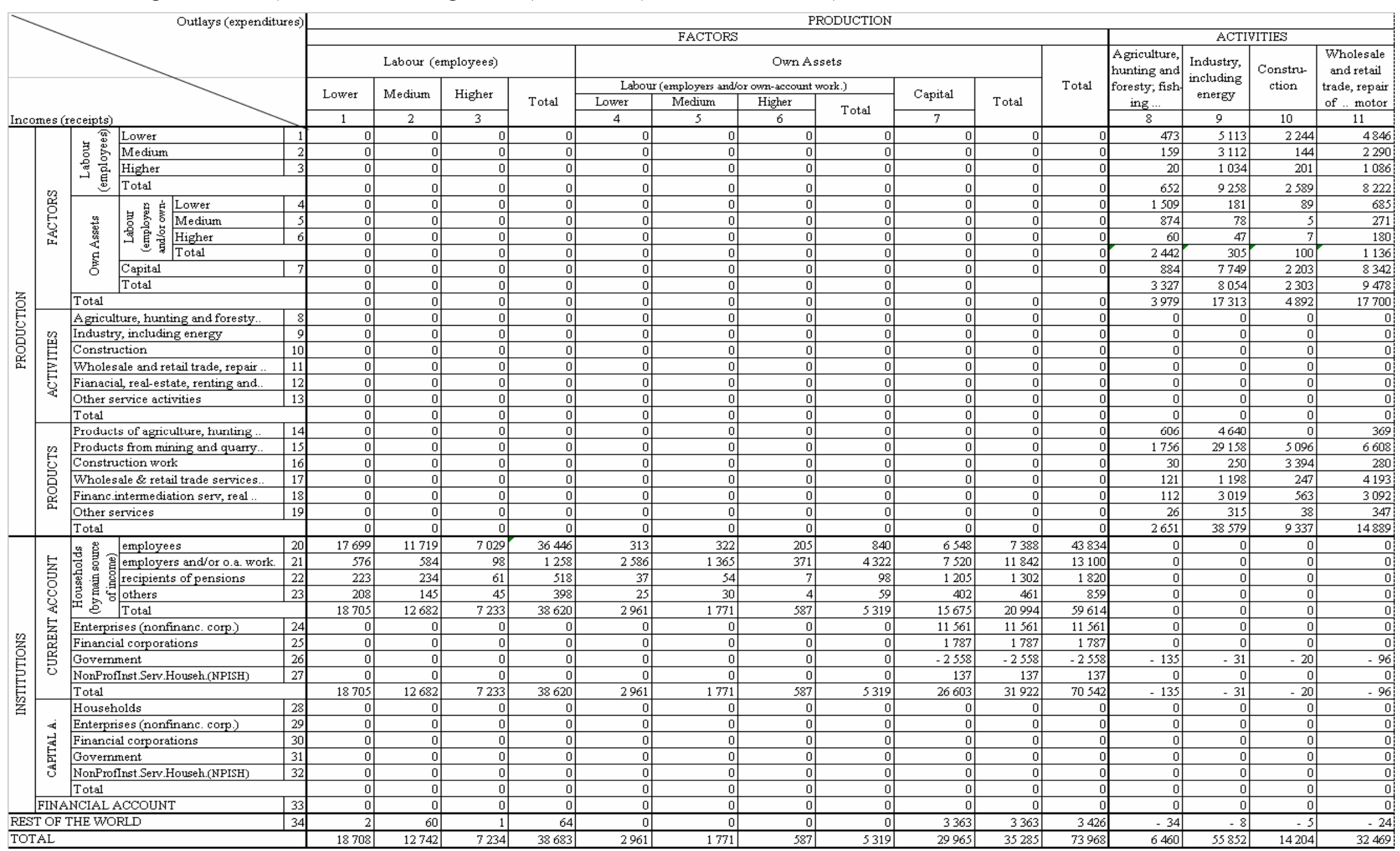

Source: Instituto Nacional de Estatística (Portuguese National Accounts and Portuguese Pilot - National Accounting Matrix, for 1995) 
Table 3. Portuguese SAM (Social Accounting Matrix) for 1995 (in millions of euros) (continued)

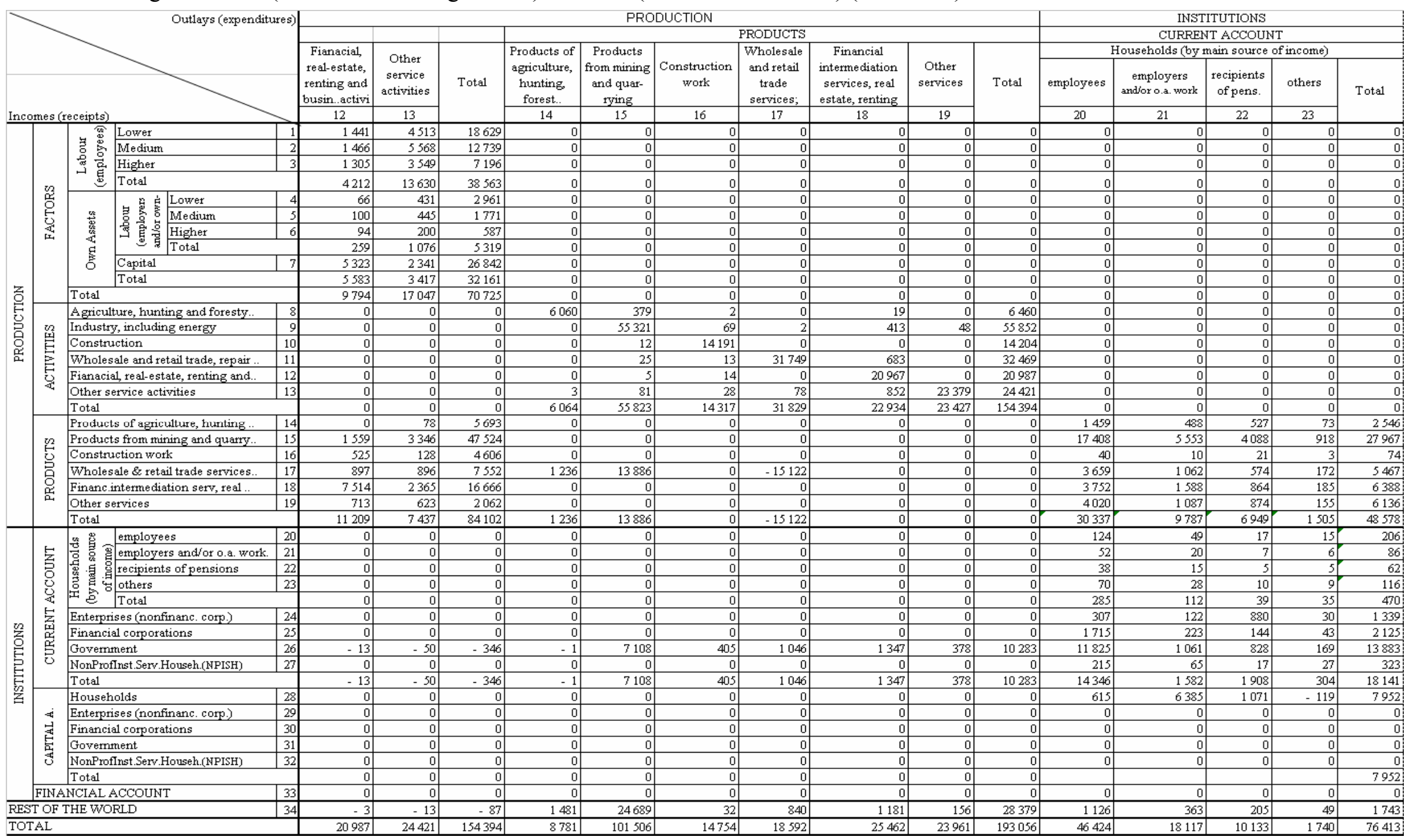

Source: Instituto Nacional de Estatística (Portuguese National Accounts and Portuguese Pilot - National Accounting Matrix, for 1995) 
Table 3. Portuguese SAM (Social Accounting Matrix) for 1995 (in millions of euros) (continued)

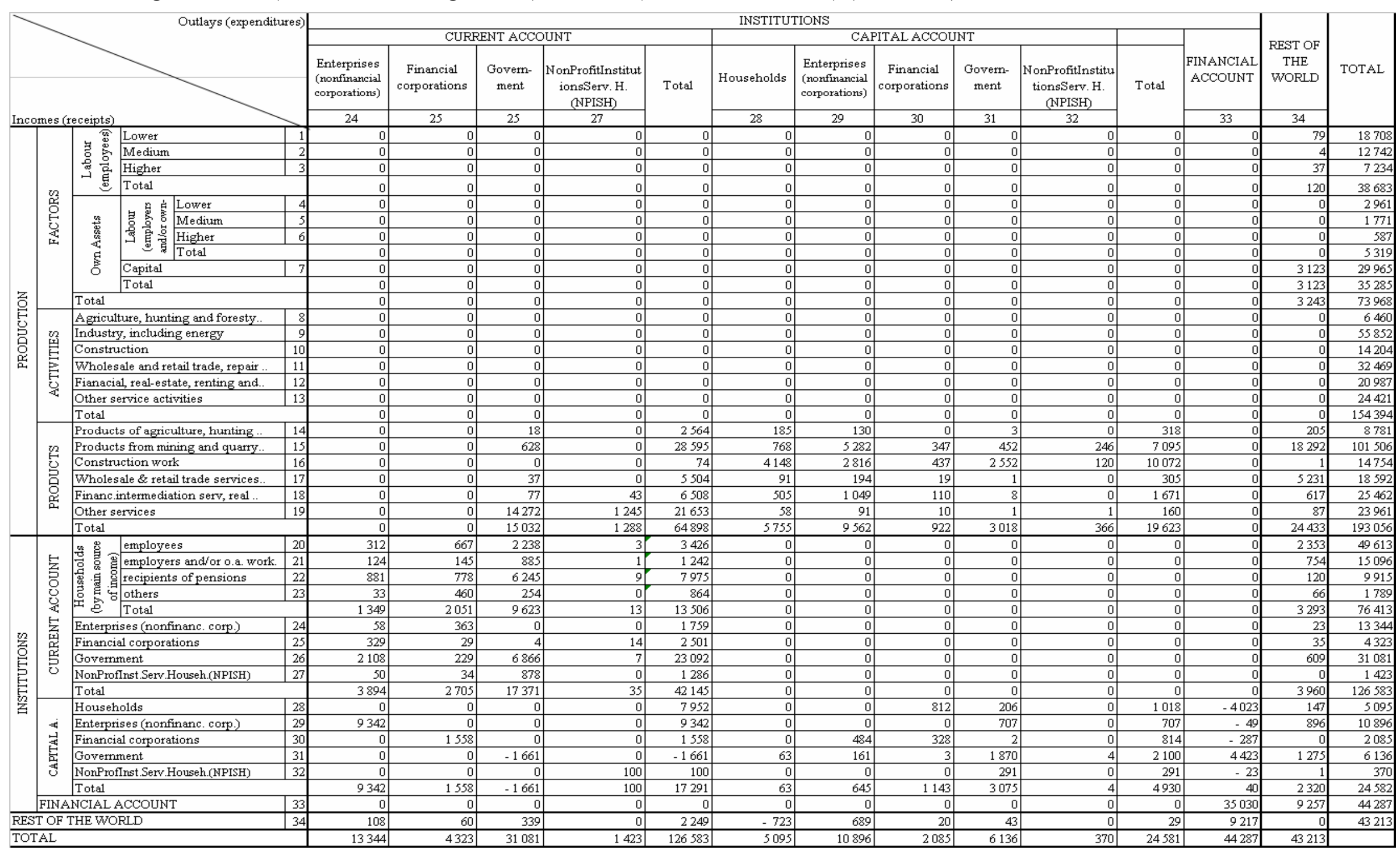

Source: Instituto Nacional de Estatística (Portuguese National Accounts and Portuguese Pilot - National Accounting Matrix, for 1995) 


\section{The algebraic version of the SAM}

\subsection{Framework and assumptions}

Now that the details inherent in the SAM that will serve as the database for the model to be designed below have been specified, the starting idea will be the one outlined in the article "Macroeconomic Modelling Based on Social-Accounting Principles" and expressed in the following words:

"A dictum usually attributed to Lord Keynes posits that every economic model has a corresponding accounting framework. For macroeconomic models, this accounting framework must be complete in the sense that every receipt must be offset by a corresponding expenditure. One consequence is that all the transactions in a model can be expressed within a SAM framework. The values assumed by all the different types of transactions can therefore be set out as the elements of a SAM" (Drud et al., 1986: 112).

Therefore, a static model will be defined and conceived as a starting point for both a comparative static and dynamic approach. On the other hand, since it will not be possible to calculate and work with price and volume indexes, a fixed-price model will be designed. Linear equations will be worked with, thereby avoiding elasticities, marginal propensities and other parameters that should be estimated from an empirical base, which is not available.

Thus, the main concern will be to capture (to begin with in a very simple way) all the national accounting transactions considered in the numerical version of the SAM (the database for this model), and, after its calibration, to conduct some experiments and define some scenarios for the aspects that the author intends to study.

The process of calibration will involve determining the parameters and exogenous variables that are to be specified, so that, after processing the model, the base SAM (presented in Section 2) is exactly replicated. The software used to process the model was the GAMS (General Algebraic Modelling System) and the quantification of the whole process took into consideration all the available information, involving the values calculated using the information contained in that same base SAM, further supplemented by additional data. These values will be assumed as valid for the "experiments and scenarios with the distributional impact of government policies", which are to be outlined in Section 6, except for those which will be subject to shocks.

Since the purpose of this model is to study income distribution, some usual specifications for the model will not be considered. These specifications include the ones that are also 
constructed within a general equilibrium framework, usually to study trade issues, such as the distinction between domestically produced and imported products, while external trade will be considered exogenous in this version of the model.

For the purposes of simplification, it will also be assumed that all domestically produced output is market output, and therefore any output produced for own final use and other nonmarket output will be considered as non-existent ${ }^{4}$.

On the other hand, it will be assumed that there is sufficient production capability available in the economy to enable domestic output to respond to aggregate demand. Such a response will be considered exclusive, since (for the time being) imports are exogenous.

Many fixed parameters will be adopted and some variables will be calculated from exogenous parameters and other variables, in order to enable future experiments to be carried out with their changes.

This model is considered to be a step forward in comparison with the ones that the author has previously worked with, and, at the same time, a (necessary) stage along a path that she would like to pursue in SAM modelling. From her own experience, the author feels that SAM modelling does have a convenient path. Thus, on the one hand, when working on SAM modelling or with SAM-based models, some knowledge of SAM construction is considered to be a necessary, although not a sufficient, condition. On the other hand, underlying SAM modelling is a process of gradual maturation, which should begin with the construction and decomposition of accounting and fixed-price multipliers and the conducting of experiments with them. That is what the author has done, based essentially on the works of Pyatt, 1988; Pyatt and Roe, 1977; and Pyatt and Round, 1985. For an illustration of this work, see Santos, 1999; 2001; 2003; 2003a; 2004; 2004a; 2005a; and 2007.

This work is the beginning of the materialisation of the step after multipliers.

\subsection{Specification by SAM blocks of sub-matrices}

As this model is supported by a SAM database, constructed in perfect consonance with the national accounts, its specifications will either obey or be derived from the SNA, as described below.

\footnotetext{
${ }^{4}$ In the year of this study, these two components together accounted for almost $13 \%$ of total output. However, considering that this model is the preliminary version of a model that will be progressively improved, they will not be considered at this stage.
} 
By convention, the parameters will be stated in lower case and the variables in upper case (at least the first letter). Endogenous variables will be written in normal letters, whereas exogenous variables, as well as the parameters, will be written in italics. The indices of each variable and parameter (the sets in the Appendix) - identified in lower-case subscripts describe the SAM accounts, the first index representing the row and the second one the column, being separated by commas. The symbols used in the description of the model will be listed alphabetically and without any indices, according to their type (endogenous or exogenous variables and parameters) in the Appendix.

The entire model will be worked upon in gross terms, so that the consumption of fixed capital will therefore not be considered.

The SAM blocks, identified in Table 4, are sub-matrices or sets of sub-matrices (as seen in the Basic SAM - Table 1) with common characteristics. The specification of these blocks will be carried out below and involves, on the one hand, an identification of the transactions of the National Accounts that are considered in the calculation of the same in the numerical SAM and, on the other hand, a definition of the equation, or system of equations, to be considered in the algebraic SAM or SAM-based model.

\subsubsection{Compensation of factors of production}

This block consists of the income of the institutional sectors originating from the compensation of the services provided through their real and financial assets to the activities of production and to the rest of the world, namely:

- Compensation of employees (transaction D1 of the National Accounts), which is broken down into wages and salaries (in cash or in kind; transaction D11) and employers' social contributions (actual and imputed social contributions; transaction D12) (SNA 93, paragraphs 7.21-7.47; ESA 95, paragraphs 4.02-4.13).

- Compensation of own-account assets, i.e. all the above-mentioned income that is not derived from the compensation of employees, including the compensation of employers and/or own-account workers, and of capital, namely property income (transaction D4 of the National Accounts). (SNA 93, paragraphs 7.87-7.133; ESA 95, paragraphs 4.41-4.76). 
Table 4. Basic SAM by blocks

\begin{tabular}{|c|c|c|c|c|c|c|c|c|}
\hline \multirow{2}{*}{\multicolumn{2}{|c|}{$\begin{array}{l}\text { Outlays } \\
\text { Incomes } \\
\text { (receipts) }\end{array}$}} & \multicolumn{3}{|c|}{ Production and Trade } & \multicolumn{3}{|c|}{ Institutions } & \multirow{2}{*}{$\begin{array}{l}\text { Rest of the World } \\
\text { (rw) }\end{array}$} \\
\hline & & Factors (f) & Activities $(a)$ & Products (p) & Current A. (dic) & Capital A. (dik) & Financial A. (dif) & \\
\hline \multirow{3}{*}{ 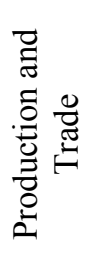 } & Factors (f) & 0 & & 0 & 0 & 0 & 0 & \\
\hline & Activities $(a)$ & 0 & 0 & Production & 0 & 0 & 0 & 0 \\
\hline & Products (p) & 0 & & $\begin{array}{c}\text { Trade and Transport } \\
\text { Margins }\end{array}$ & & & 0 & \\
\hline \multirow{3}{*}{ 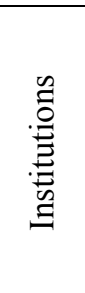 } & $\begin{array}{l}\text { Current A. } \\
\text { (dic) }\end{array}$ & & & & & 0 & 0 & \\
\hline & Capital A. (dik) & 0 & 0 & 0 & Gross Saving & & $\begin{array}{l}\text { ( -) Net lending/ } \\
\text { borrowing }\end{array}$ & \\
\hline & $\begin{array}{l}\text { Financial A. } \\
\text { (dif) }\end{array}$ & 0 & 0 & 0 & 0 & 0 & & \\
\hline \multicolumn{2}{|c|}{ Rest of the World (rw) } & & & & & & & $\mathrm{X}$ \\
\hline
\end{tabular}

Blocks with more than one sub-matrix:

Compensation of the factors of production
Domestic Trade
External Trade
Net Indirect Taxes

Current Transfers

Capital Transfers

Financial Transactions 


\subsubsection{Gross Added Value}

$$
\begin{aligned}
& \mathrm{GAV}_{a}=\beta_{a} * \mathrm{VP}_{a} \\
& \mathrm{GAV}_{\text {fle }, a}=d 1 s_{\text {fle }, a} * \mathrm{GAV}_{a} \\
& \mathrm{D} 1_{a}=\Sigma_{\mathrm{fle}} \mathrm{GAV}_{\mathrm{fle}, a} \\
& \mathrm{GAV}_{\text {fle }}=\Sigma_{a} \mathrm{GAV}_{\text {fle }, a} \\
& \mathrm{GAV}_{\text {foal }, a}=b 3 s_{\text {foal }, a} * \mathrm{GAV}_{a} \\
& \mathrm{~B} \mathrm{~g}_{a}=\Sigma_{\text {foal }} \mathrm{GAV}_{\text {foal }, a} \\
& \mathrm{GAV}_{\text {foal }}=\Sigma_{a} \mathrm{GAV}_{\text {foal }, a} \\
& \mathrm{GAV}_{\text {foak }, a}=b 2 \operatorname{gp}_{\text {foak }, a} *\left(\mathrm{D} 1_{a}+\mathrm{B}_{\mathrm{g}}\right) \\
& \mathrm{B}_{a} \mathrm{~g}_{a}=\Sigma_{\text {foak }} \mathrm{GAV}_{\text {foak }, a} \\
& \mathrm{GAV}_{\text {foak }}=\Sigma_{a} \mathrm{GAV}_{\text {foak }, a}
\end{aligned}
$$

\subsubsection{Compensation of factors from the rest of the world}

$$
\begin{aligned}
& C F R_{\mathrm{fle}, \mathrm{rw}}=D 1 R W_{\mathrm{fle}} \\
& C F R_{\mathrm{foak}, \mathrm{rw}}=D 4 R W
\end{aligned}
$$

\subsubsection{Gross National Income}

$$
\begin{aligned}
& \mathrm{GNI}_{\mathrm{fle}}=\mathrm{GAV}_{\mathrm{fle}}+C F R_{\mathrm{fle}, \mathrm{rw}}-\mathrm{CFS}_{\mathrm{rw}, \mathrm{fle}} \\
& \mathrm{GNI}_{\mathrm{dic}, \mathrm{fle}}=c e_{\mathrm{dic}, \mathrm{fle}} * \mathrm{GNI}_{\mathrm{fle}} \\
& \mathrm{GNI}_{\text {foal }}=\mathrm{GAV}_{\text {foal }} \\
& \mathrm{GNI}_{\text {dic,foal }}=c o a_{\text {dic,foal }} * \mathrm{GNI}_{\text {foal }} \\
& \mathrm{GNI}_{\text {foak }}=\mathrm{GAV}_{\text {foak }}+C F R_{\text {foak,rw }}-C F S_{\text {rw, foak }} \\
& \mathrm{GNI}_{\mathrm{dic}, \text { foak }}=s k_{\mathrm{dic}, \text { foak }} * \mathrm{GNI}_{\text {foak }} \\
& \mathrm{GNI}_{\text {dic }}=\Sigma_{\mathrm{fle}} \mathrm{GNI}_{\text {dic,fle }}+\sum_{\text {foal }} \mathrm{GNI}_{\text {dic,foal }}+\mathrm{GNI}_{\text {dic,foak }} \\
& \mathrm{GNI}=\Sigma_{\mathrm{dic}} \mathrm{GNI}_{\mathrm{dic}}
\end{aligned}
$$

\subsubsection{Compensation of factors to the rest of the world}

$$
\begin{aligned}
& \mathrm{CFS}_{\mathrm{rw}, \mathrm{fle}}=c l r_{\mathrm{rw}, \mathrm{fle}} * \mathrm{GAV}_{\mathrm{fle}} \\
& C F S_{\mathrm{rw}, \text { foak }}=D 4 P R W
\end{aligned}
$$

\subsubsection{Production}

This matrix/block represents the output of goods and services (transaction P1 of the National Accounts) (SNA 93, paragraphs 6.38-6.51; ESA 95, paragraphs 3.14-3.68). 
As assumed in section 3.1, all output will be considered as market output, which will respond exclusively to aggregate demand, since there is sufficient production capability available in the economy.

$$
\begin{aligned}
& \mathrm{VP}_{\mathrm{p}}=\mathrm{AD}_{\mathrm{p}}-\mathrm{TMT}_{\mathrm{p}}-\mathrm{NTP}_{\mathrm{p}}-I M_{\mathrm{p}} \\
& \mathrm{VP}_{a, \mathrm{p}}=\mathrm{VP}_{\mathrm{p}} * \alpha_{a, \mathrm{p}} \\
& \mathrm{VP}_{a}=\Sigma_{\mathrm{p}} \mathrm{VP}_{a, \mathrm{p}}
\end{aligned}
$$

\subsubsection{External Trade}

This block represents the transactions in goods and services (purchases, barter, gifts or grants) from non-residents to residents, or imports (transaction P7 of the National Accounts $-I M_{\mathrm{rw}, \mathrm{p}}$ ), and from residents to non-residents, or exports (transaction P6 of the National Accounts $\left.E X_{\mathrm{p}, \mathrm{rw}}\right)($ ESA 95, paragraphs 3.128-3.1465).

Although the National Accounts consider direct purchases abroad by residents $\left(\mathrm{FC}_{\mathrm{rw}, \mathrm{dic}}\right)$ as an import, in this model they will be considered as a current transfer from households to the rest of the world, considering that they will not be traded in the domestic market.

Imports are valued at c.i.f. (cost-insurance-freight included) prices (at the border of the importing country), whereas exports are valued at f.o.b. (free on board) prices (at the border of the exporting country) (ESA 95, paragraph 3.138).

In this version of the model external trade will be considered to be exogenous, as assumed in section 3.1.

\subsubsection{Net indirect taxes or net taxes on production and imports}

Net indirect taxes or the net taxes on production and imports have two main components: net taxes on production and net taxes on products, which will be treated separately in this model. On the other hand, the amount of each component will represent a receipt not only of the Portuguese general government, through the domestic institutions' current account (dicg), but also of the European Union institutions, through the rest of the world account (rw), which will also be treated separately in the model.

\footnotetext{
${ }^{5}$ The SNA 93 does not deal directly with these transactions, which are dealt with in all the other transactions with the rest of the world in its section XIV - The Rest of the World Account (external transactions account).
} 


\subsubsection{Net Taxes on Production}

This part represents the (other) taxes on production (transaction D29 of the National Accounts) minus the (other) subsidies to production (transaction D39 of the National Accounts). The former consists of all the taxes that enterprises incur as a result of engaging in production, regardless of the quantity or value of the goods and services produced or sold (SNA 93, paragraph 7.70; ESA 95, paragraphs 4.22-4.24), while the latter consists of subsidies, except those subsidies to products which resident producer units may receive as a consequence of engaging in production (SNA 93, paragraph 7.79; ESA 95, paragraphs 4.364.40).

$$
\begin{aligned}
& \mathrm{NTA}_{\mathrm{dic}, a}=n \operatorname{tag}_{\mathrm{dic}, a} * \mathrm{NTAA}_{a} \\
& \mathrm{NTA}_{\mathrm{rw}, a}=n \operatorname{tarw}_{\mathrm{rw}, a} * N T A A_{a} \\
& \mathrm{NTA}_{\mathrm{dic}}=\Sigma_{a} \mathrm{NTA}_{\mathrm{dic}, a} \\
& \mathrm{NTA}_{a}=\Sigma_{\mathrm{dic}} \mathrm{NTA}_{\mathrm{dic}, a} \\
& \mathrm{NTA}_{\mathrm{rw}}=\Sigma_{a} \mathrm{NTA}_{\mathrm{rw}, a} \\
& \mathrm{NTA}=\Sigma_{\mathrm{dic}} \mathrm{NTA}_{\mathrm{dic}}+\mathrm{NTA}_{\mathrm{rw}}
\end{aligned}
$$

\subsubsection{Net Taxes on Products}

This part represents the taxes on products (transaction D21 of the National Accounts) minus the subsidies on products (transaction D31 of the National Accounts). The former consists of taxes that are payable per unit of a good or service produced or transacted (SNA 93, paragraphs 7.62-7.69; ESA 95, paragraphs 4.16-4.21), while the latter consists of subsidies payable per unit of a good or service produced or imported (SNA 93, paragraphs 7.73-7.78; ESA 95, paragraphs 4.33-4.35).

$$
\begin{aligned}
& \mathrm{NTP}_{\mathrm{p}}=t p_{\mathrm{p}} * \mathrm{DT}_{\mathrm{p}} \\
& \mathrm{NTP}_{\mathrm{dic}, \mathrm{p}}=n t p g_{\mathrm{dic}, \mathrm{p}} * \mathrm{NTP}_{\mathrm{p}} \\
& \mathrm{NTP}_{\mathrm{rw}, \mathrm{p}}=n t p r w_{\mathrm{rw}, \mathrm{p}} * \mathrm{NTP}_{\mathrm{p}} \\
& \mathrm{NTP}_{\mathrm{dic}}=\Sigma_{\mathrm{p}} \mathrm{NTP}_{\mathrm{dic}, \mathrm{p}} \\
& \mathrm{NTP}_{\mathrm{rw}}=\Sigma_{\mathrm{p}} \mathrm{NTP}_{\mathrm{rw}, \mathrm{p}} \\
& \mathrm{NTP}=\Sigma_{\text {dic }} \mathrm{NTP}_{\mathrm{dic}}+\mathrm{NTP}_{\mathrm{rw}}
\end{aligned}
$$




\subsubsection{Trade and Transport Margins}

Trade and transport margins are realised on goods purchased for resale. They are a part of the production of wholesale trade services, retail trade services and the repair services of motor vehicles, motorcycles and personal and household goods. They are recorded as part of the trade in products and are therefore included under the various components of aggregate demand. They amount to zero, since they are negative in relation to the three abovementioned activities (because the corresponding value has already been recorded in the production sub-matrix), but are positive and have the same amount in relation to all the other ones (SNA 93, paragraphs 6.110-6.114, 15.40-15.44; ESA 95, paragraphs 3.60, 9.38-9.41).

Being realised on goods purchased for resale, and therefore excluding services (p3-p6 - SAM accounts 11-14), trade and transport margins will be considered as a function of the value of domestically transacted goods (imported and domestically produced and not exported, at c.i.f./basic prices), based on an exogenously fixed rate $(\mathrm{tm})$.

On the other hand, being a part of the production of wholesale trade services, retail trade services and the repair services of motor vehicles, motorcycles and personal and household goods (p4 and SAM account 12), which is considered in the production sub-matrix, the trade and transport margins sub-matrix will have only one non-zero row (p4 and SAM account 12). This is the one relating to the products that result from the above-mentioned resale activity, which, with the addition of a value of correction (TMc), will amount to zero, since the positive entries for the columns relating to the resale of goods (p1-p2 and SAM accounts 910) will be cancelled out by a negative entry introduced (in column p4 - SAM account 12) to avoid the double entry of the production of these activities, as referred to above.

$$
\begin{aligned}
& \mathrm{TM}_{\mathrm{p}, \mathrm{p}}=t m_{\mathrm{p}, \mathrm{p}} * \mathrm{DT}_{\mathrm{p}} \\
& \mathrm{TMc}_{\mathrm{p}, \mathrm{p}}=t m c_{\mathrm{p}, \mathrm{p}} * \mathrm{DT}_{\mathrm{p}} \\
& \mathrm{TMT}_{\mathrm{p}}=\sum_{\mathrm{p}}\left(\mathrm{TM}_{\mathrm{p}, \mathrm{p}}+\mathrm{TMc}_{\mathrm{p}, \mathrm{p}}\right) \text { (column sum) }
\end{aligned}
$$

\subsubsection{Domestic Trade}

Domestic trade is represented by the value of domestically transacted products, either domestically produced or imported. It is represented by the sub-matrices of intermediate and final consumption, as well as gross capital formation - transactions that are valued at market or purchasers' prices, i.e. having added the trade and transport margins and the net taxes on 
products to the basic prices of domestically produced products or to the c.i.f. prices of imported products.

$$
\begin{aligned}
& \mathrm{DTmp}_{\mathrm{p}}=\mathrm{VIC}_{\mathrm{p}}+\mathrm{FC}_{\mathrm{p}}+\mathrm{GCF}_{\mathrm{p}} \\
& \mathrm{DT}_{\mathrm{p}}=\mathrm{DTmp}_{\mathrm{p}}-\mathrm{TMT}_{\mathrm{p}}-\mathrm{NTP}_{\mathrm{p}}
\end{aligned}
$$

\subsubsection{Intermediate Consumption}

The intermediate consumption (transaction P2 of the National Accounts) matrix/block consists of the value of the goods and services consumed as inputs by a process of production, excluding those fixed assets whose consumption is recorded as consumption of fixed capital. The goods and services may be either transformed or used up by the production process (SNA 93, paragraphs 6.147-6.178; ESA 95, paragraphs 3.69-3.73).

$$
\begin{aligned}
& \mathrm{VIC}_{a}=\gamma_{a} * \mathrm{VP}_{a} \\
& \mathrm{VIC}_{\mathrm{p}, a}=i c p_{\mathrm{p}, a} * \mathrm{VIC}_{a} \\
& \mathrm{VIC}_{\mathrm{p}}=\Sigma_{a} \mathrm{VIC}_{\mathrm{p}, a} \\
& \mathrm{VIC}=\Sigma_{\mathrm{p}} \Sigma_{a} \mathrm{VIC}_{\mathrm{p}, a}
\end{aligned}
$$

\subsubsection{Final Consumption}

Final consumption (transaction P3 of the National Accounts) consists of the expenditure incurred by resident institutional units on those goods or services that are used for the direct satisfaction of individual needs or wants or of the collective needs of members of the community. Such consumption takes place within the domestic territory or abroad. (SNA 93, paragraphs 9.45-9.71; ESA 95, paragraphs 3.75-3.80).

Direct purchases abroad by residents $\left(\mathrm{FC}_{\mathrm{rw}, \mathrm{dic}}\right)$ are defined here, but are included in the current transfers to the rest of the world (the current transfers block).

Direct purchases by non-residents in the domestic market are included in exports (the external trade block).

$$
\begin{aligned}
& \mathrm{FC}_{\mathrm{dic}}=a p c_{\mathrm{dic}} * \mathrm{DI}_{\mathrm{dic}} \\
& \mathrm{FC}_{\mathrm{p}, \mathrm{dic}}=f c s_{\mathrm{p}, \mathrm{dic}} * \mathrm{FC}_{\mathrm{dic}} \\
& \mathrm{FC}_{\mathrm{rw}, \mathrm{dic}}=f c s r w_{\mathrm{rw}, \mathrm{dic}} * \mathrm{FC}_{\mathrm{dic}}
\end{aligned}
$$




\subsubsection{Gross Capital Formation}

The gross capital formation (transaction P5 of the National Accounts) matrix/block consists of gross fixed capital formation (transaction P51), changes in inventories (transaction P52), and acquisitions minus disposals of valuables (transaction P53) (SNA 93, paragraphs 10.3210.130; ESA 95, paragraphs 3.100-3.127).

$$
\begin{aligned}
& \mathrm{GCF}_{\mathrm{p}, \mathrm{dik}}=g f c f_{\mathrm{p}, \mathrm{dik}} * P 51_{\mathrm{dik}}+\mathrm{P} 52_{\mathrm{p}} * \operatorname{chin} v_{\mathrm{p}, \mathrm{dik}}+a d v_{\mathrm{p}, \mathrm{dik}} * \mathrm{P} 53_{\mathrm{dik}} \\
& \mathrm{GCF}_{\mathrm{dik}}=\Sigma_{\mathrm{p}} \mathrm{GCF}_{\mathrm{p}, \mathrm{dik}} \\
& \mathrm{P} 52_{\mathrm{p}}=\operatorname{chinvc_{\mathrm {p}}} * \mathrm{AS}_{\mathrm{p}} \\
& \mathrm{P} 53_{\mathrm{dik}}=a d v c_{\mathrm{dik}} * \mathrm{~S}_{\mathrm{dik}}
\end{aligned}
$$

\subsubsection{Current Transfers}

Current transfers include:

- Current taxes on income, wealth, etc. (transaction D5 of the National Accounts) (SNA 93, paragraphs 8.43-8.54; ESA 95, paragraphs 4.77-4.82).

- Social benefits and contributions (transaction D6 of the National Accounts). Social benefits are transfers to households, in cash (transaction D62) or in kind (transaction D63), intended to relieve them of the financial burden of a number of risks or needs, made either through collectively organised schemes or outside such schemes by government units and non-profit institutions serving households; they include payments from general government to producers which individually benefit households and which are made in the context of social risks or needs. Social contributions (transaction D61) include (employers' and employees') actual social contributions transferred to general government (SNA 93, paragraphs 8.67-8.83 and 8.99-8.106; ESA 95, paragraphs 4.83-4.108). Because the amount of social transfers in kind represents a final consumption expenditure of the government and the non-profit institutions serving households, it is not considered here, since it is included in the final consumption block.

- Other current transfers (transaction D7 of the National Accounts) (SNA 93, paragraphs 8.84-8.98; ESA 95, paragraphs 4.109-4.140).

- Adjustment made for the change in the net equity of households in pension fund reserves (transaction D8 of the National Accounts) (SNA 93, paragraphs 9.14-9.20; ESA 95, paragraphs 4.141-4.144). 
As already mentioned and specified above, in the section on final consumption, direct purchases abroad by residents $\left(\mathrm{FC}_{\mathrm{rw}, \mathrm{dic}}\right)$ will be added to the current transfers from households to the rest of the world.

$$
\begin{aligned}
& \mathrm{CT}_{\mathrm{dic}, \mathrm{dic}}=d 5 s_{\mathrm{dic}, \mathrm{dic}} * \mathrm{D} 5_{\mathrm{dic}}+d 61 s_{\mathrm{dic}, \mathrm{dic}} * \mathrm{D} 61_{\mathrm{dic}}+d 62 s_{\mathrm{dic}, \mathrm{dic}} * D 62 P_{\mathrm{dic}}+ \\
& \mathrm{CT}_{\mathrm{rw}, \mathrm{dic}}=d 62 r w s_{\mathrm{rw}, \mathrm{dic}} * D 62 P_{\mathrm{dic}}+d 7 r w s_{\mathrm{rw}, \mathrm{dic}} * D 7 P_{\mathrm{dic}} \\
& \mathrm{CT}_{\mathrm{dic}, \mathrm{rw}}=D 62 R W_{\mathrm{dic}, \mathrm{rw}}+D 7 R W_{\mathrm{dic}, \mathrm{rw}} \\
& \mathrm{CTR}_{\mathrm{dic}}=\Sigma_{\mathrm{dic}} \mathrm{CT}_{\mathrm{dic}, \mathrm{dic}}(\text { row sum }) \\
& \mathrm{CTP}_{\mathrm{dic}}=\Sigma_{\mathrm{dic}} \mathrm{CT}_{\mathrm{dic}, \mathrm{dic}}(\text { column sum }) \\
& \mathrm{D} 5_{\mathrm{dic}}=t i_{\mathrm{dic}, \mathrm{dic}} * \mathrm{AI}_{\mathrm{dic}} \\
& \mathrm{D} 61_{\mathrm{dic}}=s c_{\mathrm{dic}} * \mathrm{GNI}_{\mathrm{dic}}
\end{aligned}
$$

\subsubsection{Capital Transfers}

Capital transfers ${ }^{6}$ (transaction D9 of the National Accounts) cover capital taxes, investment grants and other capital transfers (SNA 93, paragraphs 10.131-10.141; ESA 95, paragraphs 4.146-4.167). Acquisitions less disposals of non-financial non-produced assets (transaction K2 of the National Accounts) - non-financial non-produced assets consisting of land and other tangible non-produced assets that may be used in the production of goods and services, as well as intangible non-produced assets (SNA 93, paragraphs 10.120-10.130; ESA 95, paragraphs 6.06-6.13) - are also covered.

$$
\begin{aligned}
& \mathrm{KT}_{\text {dik,dik }}=d 91_{\mathrm{dik}, \mathrm{dik}} * \mathrm{D} 91 \mathrm{P}_{\mathrm{dik}}+\mathrm{D} 92 \mathrm{R}_{\mathrm{dik}} * d 92_{\mathrm{dik}, \mathrm{dik}}+D 99 R_{\mathrm{dik}} * d 99_{\mathrm{dik}, \mathrm{dik}} \\
& \mathrm{KT}_{\mathrm{rw}, \mathrm{dik}}=D 92 P_{\mathrm{rw}, \mathrm{dik}}+D 99 P_{\mathrm{rw}, \mathrm{dik}}+K 2_{\mathrm{rw}, \mathrm{dik}} \\
& \mathrm{KT}_{\mathrm{dik}, \mathrm{rw}}=\mathrm{D} 92 \mathrm{R}_{\mathrm{dik}} * d 92 r w_{\mathrm{dik}, \mathrm{rw}}+D 99 R_{\mathrm{dik}} * d 99 r w_{\mathrm{dik}, \mathrm{rw}} \\
& \mathrm{D} 91 \mathrm{P}_{\mathrm{dik}}=t k_{\mathrm{dik}} * D 99 R_{\mathrm{dik}} \\
& \mathrm{D} 92 \mathrm{R}_{\mathrm{dik}}=c g f c f_{\mathrm{dik}} * P 51_{\mathrm{dik}} \\
& \mathrm{KTR}_{\mathrm{dik}}=\Sigma_{\mathrm{dik}} \mathrm{KT}_{\mathrm{dik}, \mathrm{dik}}(\text { row sum }) \\
& \mathrm{KTP}_{\mathrm{dik}}=\Sigma_{\mathrm{dik}} \mathrm{KT}_{\text {dik,dik }}(\text { column sum) }
\end{aligned}
$$

\footnotetext{
${ }^{6}$ Capital transfers are different from current transfers because they involve the acquisition or disposal of an asset, or assets, by at least one of the parties to the transaction. Whether made in cash or in kind, such transfers should result in a commensurate change in the financial, or non-financial, assets shown in the balance sheets of one or both parties to the transaction (ESA 95, paragraphs 4.145).
} 


\subsubsection{Gross Saving}

Gross saving measures the portion of aggregate income that is not used for final consumption expenditure and current transfers to Portuguese institutions or to the rest of the world (saving: SNA 93, paragraphs 9.17-9.20; ESA 95, paragraph 8.96).

Savings will therefore be the part of the disposable income (DI) that is not consumed and will represent the current budget balance of domestic institutions.

$$
\begin{aligned}
& \mathrm{S}_{\mathrm{dic}}=\left(1-a p c_{\mathrm{dic}}\right) * \mathrm{DI}_{\mathrm{dic}} \\
& \mathrm{S}_{\mathrm{dik}, \mathrm{dic}}=s i_{\mathrm{dik}, \mathrm{dic}} * \mathrm{~S}_{\mathrm{dic}} \\
& \mathrm{S}_{\mathrm{dik}}=\Sigma_{\mathrm{dik}} \mathrm{S}_{\mathrm{dik}, \mathrm{dic}}
\end{aligned}
$$

\subsubsection{Financial Transactions}

Financial transactions (F1-7 of the National Accounts) are transactions in financial assets and liabilities between institutional units, and between these and the rest of the world. They are classified as monetary gold and special drawing rights; currency and deposits; securities other than shares; loans; shares and other equity; insurance technical reserves; and other accounts receivable/payable.

The outlays (expenditures) side of the (financial) account records changes in the assets, i.e. acquisitions less disposals of financial assets. The incomes (receipts) side of the same account records changes in liabilities and net worth, i.e. the incurrence of liabilities minus their repayment. The balancing item of the financial account, i.e. the net acquisition of financial assets minus the net incurrence of liabilities, is net lending (+)/net borrowing (-) (SNA 93, paragraphs 11.1-11.111; ESA 95, paragraphs 5.01-5.151) - this will be the only endogenous part of this block in this version of the model.

$\mathrm{FTRW}_{\mathrm{dif}, \mathrm{rw}}=F T_{\mathrm{rw}, \mathrm{dif}}+\mathrm{NLB}_{\mathrm{dif}}$

\subsection{Closure - Net borrowing/lending}

The net lending (+) or borrowing (-) of the total economy is the sum of the net lending or borrowing of the institutional sectors. It represents the net resources that the total economy makes available to the rest of the world (if it is positive) or receives from the rest of the world (if it is negative). The net lending (+) or borrowing (-) of the total economy is equal (but with an opposite mathematical sign) to the net borrowing (-) or lending $(+)$ of the rest of the world (ESA 95, paragraph 8.98). 
Here, those amounts that fall short of $(+)$ or exceed (-) the investment funds used to cover aggregate investment are registered in the capital and financial accounts, since they are financial transactions either from (in the case of net borrowing) or to (in the case of net lending) the rest of the world - this is why the mathematical signs defined in the first paragraph of this item (ESA 95, paragraph 8.98) have been exchanged.

The net borrowing/lending represents the total budget balance of domestic institutions - a deficit in the case of net borrowing and a surplus in the case of net lending.

$$
\begin{aligned}
& \mathrm{NLB}_{\text {dik,dif }}=\mathrm{AINV}_{\text {dik }}-\left(\mathrm{S}_{\text {dik }}+\mathrm{KTR}_{\text {dik }}+\mathrm{KT}_{\text {dik,rw }}\right) \\
& \mathrm{NLB}_{\text {dif }}=\Sigma_{\text {dik }} \mathrm{NLB}_{\text {dik,dif }}
\end{aligned}
$$

\subsection{Clearing}

\subsubsection{Row totals}

Aggregate factors income (received):

$$
\begin{aligned}
& \mathrm{AFIR}_{\text {fle }}=\mathrm{GAV}_{\text {fle }}+C F R_{\text {fle,rw }} \\
& \mathrm{AFIR}_{\text {foal }}=\mathrm{GAV}_{\text {foal }} \\
& \mathrm{AFIR}_{\text {foak }}=\mathrm{GAV}_{\text {foak }}+C F R_{\text {floak,rw }}
\end{aligned}
$$

Production value: $\mathrm{VPT}_{a}=\Sigma_{\mathrm{p}} \mathrm{VP}_{a \mathrm{p}}$

Aggregate demand:

$$
\mathrm{AD}_{\mathrm{p}}=\mathrm{VIC}_{\mathrm{p}}+\mathrm{FC}_{\mathrm{p}}+\mathrm{GCF}_{\mathrm{p}}+E X_{\mathrm{p}, \mathrm{rw}}
$$

Aggregate income:

$$
\mathrm{AI}_{\mathrm{dic}}=\mathrm{GNI}_{\mathrm{dic}}+\mathrm{NTA}_{\mathrm{dic}}+\mathrm{NTP}_{\mathrm{dic}}+\mathrm{CTR}_{\mathrm{dic}}+\mathrm{CT}_{\mathrm{dic}, \mathrm{rw}}
$$

Investment funds:

$$
\mathrm{INVF}_{\text {dik }}=\mathrm{S}_{\mathrm{dik}}+\mathrm{KTR}_{\mathrm{dik}}+\mathrm{NLB}_{\mathrm{dik}, \mathrm{dif}}+\mathrm{KT}_{\mathrm{dik}, \mathrm{rw}}
$$

Total financial transactions:

$$
\mathrm{TFTR}_{\text {dif }}=F T_{\text {dif,dif }}+\mathrm{FTRW}_{\text {dif,rw }}
$$

Value of transactions to the rest of the world:

$$
\begin{aligned}
\text { TVRWP }_{\mathrm{rw}}=\Sigma_{\mathrm{fle}} \mathrm{CFS}_{\mathrm{rw}, \mathrm{fle}}+C F S_{\mathrm{rw}, \text { foak }}+\Sigma_{a} \mathrm{NTA}_{\mathrm{rw}, a}+\Sigma_{\mathrm{p}}\left(\mathrm{NTP}_{\mathrm{rw}, \mathrm{p}}+I M_{\mathrm{rw}, \mathrm{p}}\right)+ \\
+\Sigma_{\mathrm{dic}}\left(\mathrm{CT}_{\mathrm{rw}, \mathrm{dic}}+\mathrm{FC}_{\mathrm{rw}, \mathrm{dic}}\right)+\Sigma_{\mathrm{dik}} \mathrm{KT}_{\mathrm{rw}, \mathrm{dik}}+F T_{\mathrm{rw}, \mathrm{dif}}
\end{aligned}
$$




\subsubsection{Column totals}

Aggregate factors income (paid):

$$
\begin{aligned}
\mathrm{AFIP}_{\text {fle }} & =\mathrm{GNI}_{\text {fle }}+\mathrm{CFS}_{\mathrm{rw}, \text { fle }} \\
\mathrm{AFIP}_{\text {foal }} & =\mathrm{GNI}_{\text {foal }} \\
\mathrm{AFIP}_{\text {foak }} & =\mathrm{GNI}_{\text {foak }}+C F S_{\text {rw,foak }}
\end{aligned}
$$

Total costs:

$$
\mathrm{VCT}_{a}=\mathrm{GAV}_{a}+\mathrm{VIC}_{a}+\mathrm{NTA}_{a}+\mathrm{NTA}_{\mathrm{rw}, a}
$$

Aggregate supply:

$$
\mathrm{AS}_{\mathrm{p}}=\mathrm{VP}_{\mathrm{p}}+\mathrm{TMT}_{\mathrm{p}}+\mathrm{NTP}_{\mathrm{p}}+I M_{\mathrm{rw}, \mathrm{p}}
$$

Aggregate income:

$$
\mathrm{AIP}_{\mathrm{dic}}=\mathrm{FC}_{\mathrm{dic}}+\mathrm{CTP}_{\mathrm{dic}}+\mathrm{S}_{\mathrm{dic}}+\left(\mathrm{CT}_{\mathrm{rw}, \mathrm{dic}}+\mathrm{FC}_{\mathrm{rw}, \mathrm{dic}}\right)
$$

Aggregate investment:

$$
\mathrm{AINV}_{\mathrm{dik}}=\mathrm{GCF}_{\mathrm{dik}}+\mathrm{KTP}_{\mathrm{dik}}+\mathrm{KT}_{\mathrm{rw}, \mathrm{dik}}
$$

Total financial transactions:

$$
\mathrm{TFTP}_{\text {dif }}=\mathrm{NLB}_{\mathrm{dif}}+F T_{\mathrm{dif}, \mathrm{dif}}+F T_{\mathrm{rw}, \mathrm{dif}}
$$

Value of transactions from the rest of the world:

$$
\begin{aligned}
\text { TVRWR }_{\mathrm{rw}}=\Sigma_{\mathrm{fle}} C F R_{\mathrm{fle}, \mathrm{rw}}+C F R_{\mathrm{foa}, \mathrm{rw}}+\Sigma_{\mathrm{p}} E X_{\mathrm{p}, \mathrm{rw}}+\Sigma_{\mathrm{dic}} \mathrm{CT}_{\mathrm{dic}, \mathrm{rw}}+ \\
+\Sigma_{\text {dik }} \mathrm{KT}_{\text {dik,rw }}+\mathrm{FTRW}_{\mathrm{dif}, \mathrm{rw}}
\end{aligned}
$$

\subsubsection{Row totals $=$ column totals}

$\mathrm{AFIR}_{\text {fle }}=\mathrm{AFIP}_{\mathrm{fle}}$

$\mathrm{AFIR}_{\text {foal }}=\mathrm{AFIP}_{\text {foal }}$

$\mathrm{AFIR}_{\text {foak }}=\mathrm{AFIP}_{\text {foak }}$

$\mathrm{VPT}_{a}=\mathrm{VCT}_{a}$

$\mathrm{AD}_{\mathrm{p}}=\mathrm{AS}_{\mathrm{p}}$

$\mathrm{AI}_{\text {dic }}=\mathrm{AIP}_{\text {dic }}$

$\mathrm{INVF}_{\text {dik }}=\mathrm{AINV}_{\text {dik }}$ 
$\mathrm{TFTR}_{\mathrm{dif}}=\mathrm{TFTP}_{\mathrm{dif}}$

TVRWP $_{\mathrm{rw}}=\mathrm{TVRWR}_{\mathrm{rw}}$

\section{Macroeconomic aggregates and balances}

From the two versions of the SAM that have already been defined, it is possible to deduce macroeconomic aggregates, such as the ones described below.

Gross domestic product at market prices:

$\mathrm{GDP}=\Sigma_{a} \mathrm{GAV}_{a}+\mathrm{NTP}+\mathrm{NTA}$

GDP $=80,827$ million euros, from the numerical version.

Gross national income (at market prices):

$\mathrm{GNIMP}=\mathrm{GNI}+\Sigma_{\text {dic }} \mathrm{NTP}_{\text {dic }}+\Sigma_{\text {dic }} \mathrm{NTA}_{\text {dic }}$

GNIMP $=80,479$ million euros, from the numerical version.

Gross disposable income:

$$
\begin{aligned}
& \mathrm{DI}=\Sigma_{\mathrm{dic}} \mathrm{DI}_{\mathrm{dic}} \\
& \mathrm{DI}_{\mathrm{dic}}=\mathrm{GNI}_{\mathrm{dic}}+\mathrm{NTA}_{\mathrm{dic}}+\mathrm{NTP}_{\mathrm{dic}}+\mathrm{CTR}_{\mathrm{dic}}+\mathrm{CT}_{\mathrm{dicrw}}-\mathrm{CTP}_{\mathrm{dic}}-\mathrm{CT}_{\mathrm{rwdic}} \\
& \mathrm{DI}=83,517 \text { million euros, from the numerical version. }
\end{aligned}
$$

Gross saving:

$$
\mathrm{S}=\Sigma_{\text {dic }} \mathrm{S}_{\text {dic }}
$$

$\mathrm{S}=17,291$ million euros, from the numerical version.

Net lending/borrowing (of the economy): NLB $_{\text {dif }}$

From the numerical version, the Portuguese economy had a net borrowing of 40 million euros $(0.05 \%$ of GDP).

On the other hand, the main items in the budget of all institutions, namely of the government, can be calculated from the respective accounts. Thus: the total budget balance is the respective net lending/borrowing - $\mathrm{NLB}_{\text {dik,dif.; }}$ the current budget balance is the respective gross saving $-\mathrm{S}_{\mathrm{dik}}$; and the capital budget balance is the difference between the first and the second.

From the numerical version, Table 5 was constructed for the government and households the same procedure could also be carried out for the other institutions.

From that table, as well as from Table 3 - cells: $(28,33)-(32,33)$, it can be seen that the net borrowing of the government is almost completely covered by the net lending of households, 
although all the other institutions have a relatively small amount of net lending. In other words, the government is the institution that has a total budget balance with a deficit, which is almost completely covered by the other institutions, with households being in a highly significant position, which is, however, not sufficient to avoid a net borrowing for the economy of 40 million euros ( $0.05 \%$ of GDP). In terms of the current balance, or gross saving (see also Table 3 - cells: $(28,20)-(32,27))$, the government is again the institution that has a deficit, although, within households, the group labelled as "others" (those whose main source of income is not wages and salaries, mixed income including property income or income in connection with old age) also has a deficit. Therefore, with the exception of the government, all the institutions covered their needs in terms of investment funds, as well as a substantial part of those of the government.

From Table 5, it is easy to see how current transfers from Portuguese institutions and net taxes on products are the main sources of the government's receipts, while current transfers to Portuguese institutions and final consumption are the main sources of its expenditure. In the case of households, the income generated by these (or gross national income) and final consumption are, respectively, the main sources of receipts and expenditure.

In turn, the main items of the balance of payments can also be calculated from the rest of the world account. However, this will not be done here, because the relations with the rest of the world were not considered relevant within the framework of this paper - see Santos, 2006. 
Table 5. The Government and Households Budget in the Portuguese SAM for 1995 (in millions of euros)

\begin{tabular}{|c|c|c|c|c|c|c|c|c|}
\hline & \multicolumn{3}{|c|}{ Resources or Receipts (row) } & \multicolumn{3}{|c|}{ Uses or Expenditure (column) } & \multicolumn{2}{|c|}{ Balance } \\
\hline & & Government & Households & & Government & Households & Government & Households \\
\hline \multirow[t]{6}{*}{$\begin{array}{l}\text { 1. Current } \\
\text { Account (a) }\end{array}$} & & 31081 & 76413 & & 32742 & 68461 & -1661 & 7952 \\
\hline & $\begin{array}{l}\text { Gross National Income at } \\
\text { factor cost (a) }\end{array}$ & -2558 & 59614 & Final Consumption & 15032 & 49905 & & \\
\hline & Net taxes on production & -346 & - & $\begin{array}{l}\text { Current transfers to Portuguese } \\
\text { institutions }\end{array}$ & 17371 & 18141 & & \\
\hline & Net taxes on products & 10283 & - & Current transfers to the RW & 339 & 416 & & \\
\hline & $\begin{array}{l}\text { Current transfers from } \\
\text { Portuguese institutions } \\
\end{array}$ & 23092 & 13506 & & & & & \\
\hline & $\begin{array}{l}\text { Current transfers from } \\
\text { the RW }\end{array}$ & 609 & 3293 & & & & & \\
\hline \multirow[t]{4}{*}{$\begin{array}{l}\text { 2. Capital } \\
\text { Account }\end{array}$} & & 3375 & 1166 & & 6136 & 5095 & -2761 & -3929 \\
\hline & $\begin{array}{l}\text { Capital transfers from } \\
\text { Portuguese institutions }\end{array}$ & 2100 & 1018 & Gross Capital Formation & 3018 & 5755 & & \\
\hline & $\begin{array}{l}\text { Capital transfers from } \\
\text { the RW }\end{array}$ & 1275 & 147 & $\begin{array}{l}\text { Capital transfers to Portuguese } \\
\text { institutions }\end{array}$ & 3075 & 63 & & \\
\hline & & & & Capital transfers to the RW & 43 & -723 & & \\
\hline $3=1+2(b)$ & & 34456 & 77579 & & 38878 & 73556 & -4423 & 4023 \\
\hline
\end{tabular}

Source: Table 2 (rows/columns 18 and 23)

(a) Balance $=$ Gross saving $\left(\mathrm{S}_{\mathrm{dikg}}\right.$ for government; $\mathrm{S}_{\mathrm{dikh}}$ for households).

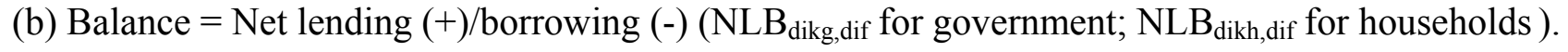




\section{The structural indicators of the distribution and use of income}

Considering that the distributional relationships across production sectors or activities and social groups are determined by the macro behaviour, which, in turn, is determined by the behaviour of individuals within and on behalf of institutions, this means that if we are to study the distributional impact of exogenous shocks resulting from any policy, as proposed in the Introduction (Section 1) and exemplified in Section 6, it is important to have some indicators that, in addition to the macroeconomic aggregates and balances, synthesise that impact as much as possible. Therefore, two aspects will be considered: the distribution of generated income and the distribution and use of disposable income.

Due to a lack of information about the total number of persons by groups of households, only the structures of the distribution and use of income will be considered here - leaving the identification of inequality for a subsequent stage.

\section{A. Distribution of generated income}

\section{A.1. Among factors of production and activities}

The functional distribution of income can be studied here through an analysis of the division of gross added value at factor cost (excluding indirect taxes) between labour and capital, disaggregated by activity. It is also important to distinguish between types of labour (Dervis et al., 1982) - in this case by the level of education of workers.

$$
\begin{aligned}
& \operatorname{Digav}_{\mathrm{fle}, a}=\left(\mathrm{D} 1_{a} / \mathrm{GAV}_{a}\right) * 100 \\
& \operatorname{Digav}_{\mathrm{foal}, a}=\left(\mathrm{B} 3 \mathrm{~g}_{a} / \mathrm{GAV}_{a}\right) * 100 \\
& \operatorname{Digav}_{\mathrm{foak}, a}=\left(\mathrm{B} 2 \mathrm{~g}_{a} / \mathrm{GAV}_{a}\right) * 100 \\
& \operatorname{Digav}_{\mathrm{fle}}=\left(\Sigma_{a} \mathrm{D} 1_{a} / \Sigma_{a} \mathrm{GAV}_{a}\right) * 100 \\
& \operatorname{Digav}_{\mathrm{foal}}=\left(\Sigma_{a} \mathrm{~B} 3 \mathrm{~g}_{a} / \Sigma_{a} \mathrm{GAV}_{a}\right) * 100 \\
& \operatorname{Digav}_{\mathrm{foak}}=\left(\Sigma_{a} \mathrm{~B} 2 \mathrm{~g}_{a} / \Sigma_{a} \mathrm{GAV}_{a}\right) * 100 \\
& \operatorname{Digavfle}_{\mathrm{fle}, a}=\left(\mathrm{GAV}_{\mathrm{fle}, a} / \mathrm{D} 1_{a}\right) * 100 \\
& \operatorname{Digavfoal}_{\mathrm{foal}, a}=\left(\mathrm{GAV}_{\mathrm{foal}, a} / \mathrm{B} 3 \mathrm{~g}_{a}\right) * 100 \\
& \text { Digavfle }_{\mathrm{fle}}=\left(\mathrm{GAV}_{\mathrm{fle}} / \Sigma_{a} \mathrm{D} 1_{a}\right) * 100 \\
& \text { Digavfoal }_{\mathrm{foal}}=\left(\mathrm{GAV}_{\mathrm{foal}} / \Sigma_{a} \mathrm{~B} 3 \mathrm{~g}_{a}\right) * 100
\end{aligned}
$$

The following tables were constructed from the numerical version of the SAM - the links to the algebraic version are shown between brackets. 
A SAM-based model, constructed from the SNA, to be used for studying the distributional impacts of government policies in Portugal. S. Santos

Table 6. Distribution of gross added value, at factor cost, among factors of production and activity, in the Portuguese SAM for 1995 (in percentage terms).

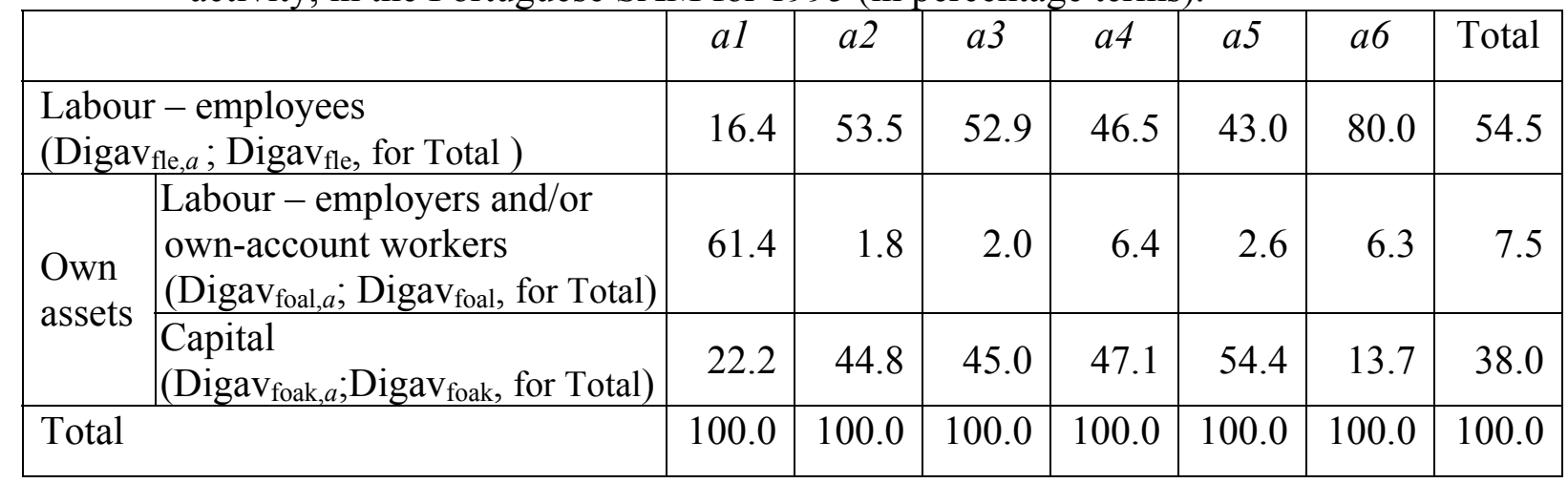

Source: Table 3.

Table 7. Distribution of gross added value, at factor cost, generated by labour by the level of education of workers and activity, in the Portuguese SAM for 1995 (in percentage terms).

\begin{tabular}{|c|c|c|c|c|c|c|c|c|}
\hline & & $a 1$ & $a 2$ & $a 3$ & $a 4$ & $a 5$ & $a 6$ & Total \\
\hline \multirow{4}{*}{$\begin{array}{l}\text { Employees } \\
\text { with } \\
\text { (Digavfle }_{\text {fle }, a} ; \\
\text { Digavfle }_{\text {fle }}, \text { for } \\
\text { (row) Total) }\end{array}$} & low education level & 72.5 & 55.2 & 86.7 & 58.9 & 34.2 & 33.1 & 48.3 \\
\hline & $\begin{array}{l}\text { medium education } \\
\text { level }\end{array}$ & 24.4 & 33.6 & 5.6 & 27.9 & 34.8 & 40.9 & 33.0 \\
\hline & high education level & 3.1 & 11.2 & 7.8 & 13.2 & 31.0 & 26.0 & 18.7 \\
\hline & Total & 100.0 & 100.0 & 100.0 & 100.0 & 100.0 & 100.0 & 100.0 \\
\hline \multirow{4}{*}{$\begin{array}{l}\text { Employers } \\
\text { and/or own- } \\
\text { account } \\
\text { workers with } \\
\text { (Digavfoal }_{\text {foal }, a} \\
\text { Digavfoal } \\
\text { for (row) Toatal) }\end{array}$} & & 61.8 & 59.3 & 89.0 & 60.3 & 25.3 & 40.1 & 55.7 \\
\hline & $\begin{array}{l}\text { medium education } \\
\text { level }\end{array}$ & 35.8 & 25.5 & 4.5 & 23.8 & 38.5 & 41.3 & 33.3 \\
\hline & high education level & 2.5 & 15.2 & 6.5 & 15.8 & 36.2 & 18.6 & 11.0 \\
\hline & Total & 100.0 & 100.0 & 100.0 & 100.0 & 100.0 & 100.0 & 100.0 \\
\hline
\end{tabular}

Source: Table 3.

Key to activities:

al - agriculture, hunting and forestry; fishing and operation of fish hatcheries and fish farms;

$a 2$ - industry, including energy;

$a 3$ - construction;

$a 4$ - wholesale and retail trade, repair of motor vehicles and household goods, hotels and restaurants; transport and communications;

a5 - financial, real estate, renting and business activities;

$a 6$ - other service activities. 
Thus, wages and salaries, or the compensation of labour received by employees, represent $54.5 \%$ of generated income, whereas the compensation of labour received by the employers and/or own-account workers represents $7.5 \%$. Within these two parts of generated income, almost half (48.3\%), in the first case and more than half $(55.7 \%)$, in the second case, is received by workers with a low education level while, in both cases, workers with a medium education level receive $33.3 \%$ and those with a high education level receive the remainder. Capital, therefore, represents $38 \%$ of generated income. This general structure is the result of a relative heterogeneity in the distributions (of generated income) among activities. The group of activities of "agriculture, hunting and forestry; fishing and operation of fish hatcheries and fish farms" $(a 1)$ is the one that contributes most to that heterogeneity, with wages and salaries representing only $16.4 \%$ and the compensation of labour received by employers and/or ownaccount workers representing $61.4 \%$ - resulting in one of the lowest shares for the compensation of capital (22.2\%, after the other service activities - group a6 - with 13.7\%). This group of activities also has one of the highest shares of workers with a low education level (employees - 72.5\% - and employers and/or own-account workers - $61.8 \%$, after construction - group $a 3$ - with $86.9 \%$ and $89 \%$, respectively).

\section{A.2. Among institutions and socioeconomic groups, within households}

By excluding from the gross added value at factor cost generated in the domestic economy the compensation of the factors of production sent to the rest of the world, and by including the compensation of the factors of production received from the rest of the world (in accordance with equation (3.17)), the gross national income is obtained and its institutional distribution can be studied.

$\operatorname{Digni}_{\mathrm{dic}}=\left(\mathrm{GNI}_{\mathrm{dic}} / \mathrm{GNI}\right) * 100$

Table 8. Distribution of gross national income, at factor cost, among institutions and socioeconomic groups, within households, in the Portuguese SAM for 1995 (in percentage terms).

\begin{tabular}{|l|r|l|c|}
\hline $\begin{array}{l}\text { Group of households } \\
\text { (in accordance with the main source of income) }\end{array}$ & \multicolumn{2}{|c|}{ Other Institutions } \\
\hline Employees & $62.1 \%$ & $\begin{array}{l}\text { Non-financial } \\
\text { corporations }\end{array}$ & $16.4 \%$ \\
\hline $\begin{array}{l}\text { Employers (including own } \\
\text { account workers) }\end{array}$ & $18.6 \%$ & Financial corporations & $2.5 \%$ \\
\hline Recipients of pensions & $2.6 \%$ & General government & $-3.6 \%$ \\
\hline Others & $1.2 \%$ & Non-profit institutions & $0.2 \%$ \\
\hline
\end{tabular}


A SAM-based model, constructed from the SNA, to be used for studying the distributional impacts of government policies in Portugal. S. Santos

\begin{tabular}{|l|l|l|l|}
\hline & & serving households & \\
\hline Total (households) & $84.5 \%$ & Total (all Institutions) & $100.0 \%$ \\
\hline
\end{tabular}

Source: Table 3.

As a result of what was seen with regard to the position of the compensation of labour in generated income, households receive $84.5 \%$ of gross national income, with $62.1 \%$ corresponding to the group whose main source of income is wages and salaries (employees). Non-financial corporations receive $16.4 \%$, with the remainder being distributed amongst the other institutions and with the general government recording a negative share.

B. Distribution and use of disposable income, among institutions and socioeconomic groups, within households.

By excluding from gross national income the current transfers paid to other institutions and to the rest of the world, and by including the current transfers received from the other institutions and from the rest of the world and, in the case of the government, the net indirect taxes (in accordance with equation (4.4)), the institutional distribution of gross disposable income can also be studied. In turn, the use made of gross disposable income is divided into final consumption and saving, although non-financial and financial corporations do not have any final consumption.

$\operatorname{Didi}_{\mathrm{dic}}=\left(\mathrm{DI}_{\mathrm{dic}} / \mathrm{DI}\right) * 100$

$\mathrm{UdiFC}_{\mathrm{dic}}=\left(\mathrm{FC}_{\mathrm{dic}} / \mathrm{DI}_{\mathrm{dic}}\right) * 100$

$\mathrm{UdiS}_{\mathrm{dic}}=\left(\mathrm{S}_{\mathrm{dic}} / \mathrm{DI}_{\mathrm{dic}}\right) * 100=100-\mathrm{UdiFC}_{\mathrm{dic}}$

From the numerical version:

Table 9. Distribution and use of disposable income, among institutions and socioeconomic groups, within households, in the Portuguese SAM for 1995 (in percentage terms).

\begin{tabular}{|c|c|c|c|c|}
\hline & \multirow{2}{*}{$\begin{array}{l}\text { Distribution of } \\
\text { Disposable } \\
\text { Income }\end{array}$} & \multicolumn{2}{|c|}{$\begin{array}{l}\text { Use of Disposable } \\
\text { Income }\end{array}$} \\
\hline & & & $\begin{array}{c}\text { Final } \\
\text { Consumption }\end{array}$ & Saving \\
\hline \multirow{5}{*}{$\begin{array}{l}\text { Group of } \\
\text { households } \\
\text { (in accordance } \\
\text { with the main } \\
\text { source of } \\
\text { income) }\end{array}$} & Employees & 41.9 & 98.2 & 1.8 \\
\hline & $\begin{array}{l}\text { Employers (including own } \\
\text { account workers) }\end{array}$ & 16.1 & 52.4 & 47.6 \\
\hline & Recipients of pensions & 9.6 & 86.6 & 13.4 \\
\hline & Others & 1.8 & 108.0 & -8.0 \\
\hline & Total (households) & 69.3 & 86.3 & 13.7 \\
\hline
\end{tabular}




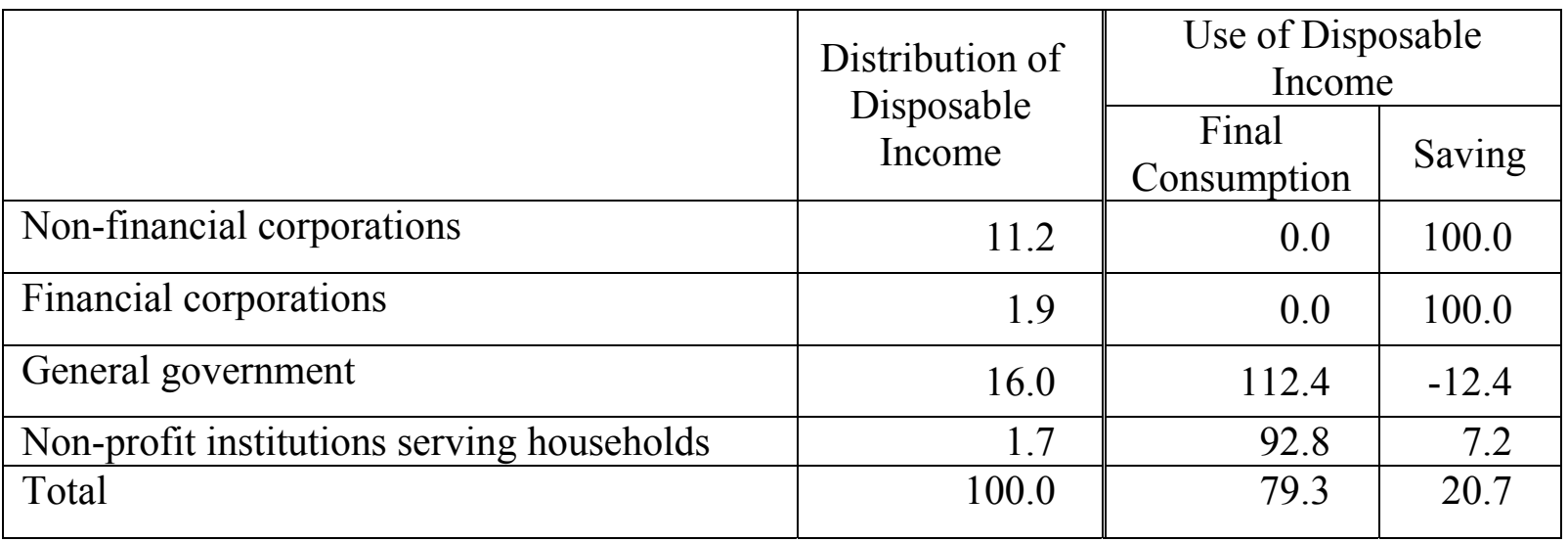

Source: Table 3.

Therefore, households have $69.3 \%$ of disposable income, with the group whose main source of income is wages and salaries (employees) having $41.9 \%$. The general government has a share of $16 \%$ (similar to the group of households whose main source of income is the compensation of labour received by employers, including own account workers), while the share of non-financial corporations is $11.2 \%$; the other shares are less significant. Except in the case of the non-financial and financial corporations, final consumption absorbs the most significant part of disposable income, even exceeding it in the case of both the general government and the group "others" amongst the households (those whose main source of income is not wages and salaries, mixed income including property income or income in connection with old age).

More specific and exact conclusions would require specification of the households' composition - number of workers by household, size, age composition, dependency ratios, etc. (Dervis et al., 1982).

\section{Experiments and scenarios with the distributional impact of budget policies}

Considering the framework, assumptions and purposes of this version of the algebraic SAM, two experiments were carried out involving current transfers from/to households.

Because the intention was to study the distributional impacts of government policies, two scenarios were defined. The first scenario (scenario A) considered a $1 \%$ reduction in the direct tax rate $(t i)$ paid by households to the government, while scenario B was based on a $1 \%$ increase in social benefits other than social transfers in kind $(D 62 P)$ paid by the government to households. 
With the help of Table 5 (and 3), it can be seen that in scenario A, the reduction in the current taxes on income, wealth, etc. will involve a leakage from the government's main source of receipts (current transfers from households) and an injection (of receipts, resulting from the reduction in expenditure) into one item of the expenditure of households (current transfers to the government), although not the most important one. In turn, the increase in social benefits other than social transfers in kind, occurring in scenario B, will involve an injection into one source of the receipts of households (current transfers from government), although not the most important one, and a leakage (of receipts, resulting from the increase in expenditure) from the main item of government expenditure (current transfers to households).

The immediate purpose of these two experiments is to improve the financial situation of households.

Table 10 shows the base values and the corresponding relative importance of the flows that were subjected to the above-mentioned shocks.

Table 10. Current taxes on income, wealth, etc. paid by households to the government and social benefits other than social transfers in kind paid by the government to households, in Portugal in 1995.

\begin{tabular}{|c|c|c|c|c|}
\hline \multirow{2}{*}{$\begin{array}{l}\text { Group of households } \\
\text { (in accordance with the main source of } \\
\text { income) }\end{array}$} & \multicolumn{2}{|c|}{$\begin{array}{l}\text { Current taxes on income, } \\
\text { wealth, etc. }{ }^{\text {(a) }}\end{array}$} & \multicolumn{2}{|c|}{$\begin{array}{l}\text { Social benefits other than } \\
\text { social transfers in kind }^{(c)}\end{array}$} \\
\hline & $\begin{array}{l}\text { millions of } \\
\quad \text { euros }\end{array}$ & $\begin{array}{c}\text { direct tax } \\
\text { rate }^{(b)} \\
(\%)\end{array}$ & $\begin{array}{l}\text { millions of } \\
\text { euros }\end{array}$ & $\begin{array}{l}\% \text { of } \\
\mathrm{DI}^{(\mathrm{d})}\end{array}$ \\
\hline Employees & 4201 & 8.5 & 2206 & 6.3 \\
\hline $\begin{array}{l}\text { Employers } \\
\text { (including own account workers) }\end{array}$ & 377 & 2.5 & 873 & 6.5 \\
\hline Recipients of pensions & 294 & 3.0 & 6156 & 77.0 \\
\hline Others & 60 & 3.4 & 250 & 16.9 \\
\hline Total (households) & 4932 & 6.5 & 9485 & 16.4 \\
\hline
\end{tabular}

Source: Instituto Nacional de Estatística (Portuguese National Accounts and Portuguese Pilot SAM - National Accounting Matrix, for 1995)

Notes:

(a) Transaction D5 of the National Accounts. See Section 2 for the methodology used in adjusting the total value to the values of the groups of households.

(b) Current taxes on income, wealth, etc. paid by households to the government, per unit of received aggregate income $(t i)$.

(c) Transaction D62 of the National Accounts (D62P). See Section 2 for the methodology used in adjusting the total value to the values of the groups of households. 
(d) Social benefits other than social transfers in kind paid by the government to households, per unit of disposable income of households.

The framework within which scenario A will be defined and the first experiment performed shows that the direct taxes, or the current taxes on income, wealth, etc. paid by households, represent $6.5 \%$ of their aggregate income (households pay $68.9 \%$ of the direct taxes paid by all the institutions). Employees pay $8.5 \%$ of their aggregate income, which is the highest direct rate within the groups of households (they also pay $58.7 \%$ of the direct taxes paid by all the institutions and $85.2 \%$ of those paid by households). Employers and own account workers pay the lowest rate: $2.5 \%$.

Scenario B will be defined within a framework in which social benefits other than social transfers in kind represent $16.4 \%$ of the disposable income of households, with the recipients of pensions having the largest share in the case of this item, with such benefits being responsible for $77 \%$ of their disposable income (the corresponding amount is $25 \%$ higher than the direct taxes paid by households).

At the level of macroeconomic aggregates and balances, as defined in Section 4, the main impacts of the two scenarios can be seen in Table 11 .

Table 11. Impacts (percentage change) on the macroeconomic aggregates of a reduction (of $1 \%$ ) in the direct tax rate paid by households to the government - scenario A, and of an increase (of 1\%) in the social benefits other than social transfers in kind received by households from the government - scenario B.

\begin{tabular}{|c|c|c|c|c|}
\hline \multicolumn{3}{|c|}{ Macroeconomic Aggregates } & Scenario A & Scenario B \\
\hline \multicolumn{3}{|c|}{ Gross domestic product at market prices (GDP) } & $-1.47 \%$ & $-0.19 \%$ \\
\hline \multicolumn{3}{|c|}{ Gross national income (at market prices) (GNIMP) } & $-1.47 \%$ & $-0.19 \%$ \\
\hline \multirow{10}{*}{$\begin{array}{l}\text { Gross } \\
\text { Disposable } \\
\text { Income (DI), } \\
\text { of: }\end{array}$} & \multirow{5}{*}{$\begin{array}{l}\text { Group of } \\
\text { households } \\
\text { (in accordance } \\
\text { with the main } \\
\text { source of } \\
\text { income) }\end{array}$} & Employees & $-0.24 \%$ & $-0.15 \%$ \\
\hline & & $\begin{array}{l}\text { Employers } \\
\text { (including own account workers) }\end{array}$ & $+0.07 \%$ & $-0.07 \%$ \\
\hline & & Recipients of pensions & $+1.13 \%$ & $+0.73 \%$ \\
\hline & & Others & $+0.54 \%$ & $+0.08 \%$ \\
\hline & & Total (households) & $+0.04 \%$ & $0.00 \%$ \\
\hline & \multicolumn{2}{|c|}{ Non-financial corporations } & $-1.18 \%$ & $-0.17 \%$ \\
\hline & \multicolumn{2}{|c|}{ Financial corporations } & $-2.73 \%$ & $-0,35 \%$ \\
\hline & \multicolumn{2}{|c|}{ General government } & $-7.90 \%$ & $-0.97 \%$ \\
\hline & \multicolumn{2}{|c|}{ Non-profit institutions serving households } & $-0.11 \%$ & $-0.01 \%$ \\
\hline & \multicolumn{2}{|l|}{ Total } & $-1.42 \%$ & $-0.18 \%$ \\
\hline
\end{tabular}


A SAM-based model, constructed from the SNA, to be used for studying the distributional impacts of government policies in Portugal. S. Santos

\begin{tabular}{|l|r|r|}
\hline \multicolumn{1}{|c|}{ Macroeconomic Aggregates } & Scenario A & Scenario B \\
\hline Gross Saving (S) & $-0.04 \%$ & $-0.01 \%$ \\
\hline Net Borrowing of the economy (NLB) & $+6.29 \%$ & $+4.63 \%$ \\
\hline
\end{tabular}

Source: Table 3 and other data provided by the Instituto Nacional de Estatística (Portuguese National Accounts and Portuguese Pilot SAM - National Accounting Matrix, for 1995) for the construction of Table 3 and for the calculation of the parameters used in the model defined in Section 3 (from which the values shown in this table were derived).

Therefore, in scenario A, a reduction of $1 \%$ in the direct tax rate paid by households to the government resulted in a decrease of $1.47 \%$ in the gross domestic product at market prices (GDP), as well as, in the gross national income at market prices (GNIMP). The disposable income (DI) of households only increased by $0.04 \%$ and, curiously, employees, who pay the major share of direct taxes, are the only group of households that shows a decrease, due to the importance of generated income (gross national income, which decreased by $1.47 \%$ ) in their disposable income. The other institutions showed a generalized decrease in their DI, particularly the government, with a decrease of $7.9 \%$, which had a consequent negative impact on both demand and production. This situation is proved by the decreases in GDP and GNIMP, as mentioned above, as well as in the gross saving and net borrowing of the economy, the latter showing a significant increase of $6.29 \%$.

The impacts in scenario B were not so significant, although the percentage changes almost always have the same mathematical sign. Thus, the increase of $1 \%$ in the social benefits other than social transfers in kind received by households from the government resulted in decreases of $0.19 \%$ in GDP and GNIMP, with the DI of households being maintained resulting from decreases in employees $(-0.15 \%)$ and employers $(-0.07 \%)$ and increases in recipients of pensions $(+0.73 \%)$ and others $(+0.08 \%)-$ and a generalized decrease in the DI of the other institutions, with the highest value (-0.97\%) being recorded by the government. The explanation for this process is identical to the one provided for scenario A, although in this case the effects on GDP and GNIMP $(-0.19 \%)$ and on gross saving $(+0.01 \%)$ were smaller, as well as on the net borrowing of the economy, which increased by $4.63 \%$.

The dependence of final consumption on the gross disposable income of all domestic institutions, including the government, as well as the relationship between aggregate demand and production, are certainly the main causes of these results. 
A SAM-based model, constructed from the SNA, to be used for studying the distributional impacts of government policies in Portugal. S. Santos

At the level of the balances, namely, at the level of the budgets of the institutions, the impacts on the current balances, expressed by gross saving, and on the total balances, expressed by the net lending/borrowing, are shown in Table 12.

Table 12. Impacts (percentage change) on the budget balances of the institutions of a reduction (of $1 \%$ ) in the direct tax rate paid by households to the government scenario $\mathrm{A}-$ and of an increase (of $1 \%$ ) in the social benefits other than social transfers in kind received by households from the government - scenario B.

\begin{tabular}{|c|c|c|c|c|}
\hline \multicolumn{3}{|c|}{ Budget Balances of the institutions } & Scenario A & Scenario B \\
\hline \multirow{10}{*}{$\begin{array}{l}\text { Current } \\
\text { balance } \\
\text { of: }\end{array}$} & \multirow{5}{*}{$\begin{array}{l}\text { Group of } \\
\text { households } \\
\text { (in accordance } \\
\text { with the main } \\
\text { source of } \\
\text { income) }\end{array}$} & Employees & $-0.24 \%$ & $-0.15 \%$ \\
\hline & & $\begin{array}{l}\text { Employers } \\
\text { (including own account workers) }\end{array}$ & $+0.07 \%$ & $-0.07 \%$ \\
\hline & & Recipients of pensions & $+1.13 \%$ & $+0.73 \%$ \\
\hline & & Others & $+0.54 \%$ & $+0.08 \%$ \\
\hline & & Total (households) & $+0.18 \%$ & $+0.03 \%$ \\
\hline & \multicolumn{2}{|c|}{ Non-financial corporations } & $-1.18 \%$ & $-0.17 \%$ \\
\hline & \multicolumn{2}{|c|}{ Financial corporations } & $-2.73 \%$ & $-0.35 \%$ \\
\hline & \multicolumn{2}{|c|}{ General government } & $-7.90 \%$ & $-0.97 \%$ \\
\hline & \multicolumn{2}{|c|}{ Non-profit institutions serving households } & $-0.11 \%$ & $-0.01 \%$ \\
\hline & \multicolumn{2}{|l|}{ Total } & $-0.04 \%$ & $-0.01 \%$ \\
\hline \multirow{6}{*}{$\begin{array}{l}\text { Capital } \\
\text { balance } \\
\text { of: }\end{array}$} & \multicolumn{2}{|l|}{ Households } & $-0.02 \%$ & $0.00 \%$ \\
\hline & \multicolumn{2}{|c|}{ Non-financial corporations } & $-0.03 \%$ & $0.00 \%$ \\
\hline & \multicolumn{2}{|c|}{ Financial corporations } & $-0.01 \%$ & $0.00 \%$ \\
\hline & \multicolumn{2}{|c|}{ General government } & $0.00 \%$ & $0.00 \%$ \\
\hline & \multicolumn{2}{|c|}{ Non-profit institutions serving households } & $-0.09 \%$ & $-0.07 \%$ \\
\hline & \multicolumn{2}{|l|}{ Total } & $-0.02 \%$ & $0.00 \%$ \\
\hline \multirow{6}{*}{$\begin{array}{l}\text { Total } \\
\text { balance } \\
\text { of: }\end{array}$} & \multicolumn{2}{|l|}{ Households } & $+0.38 \%$ & $+0.06 \%$ \\
\hline & \multicolumn{2}{|c|}{ Non-financial corporations } & $-215.73 \%$ & $-30.40 \%$ \\
\hline & \multicolumn{2}{|c|}{ Financial corporations } & $-14.74 \%$ & $-1.89 \%$ \\
\hline & \multicolumn{2}{|c|}{ General government } & $-2.97 \%$ & $-0.36 \%$ \\
\hline & \multicolumn{2}{|c|}{ Non-profit institutions serving households } & $-0.19 \%$ & $+0.18 \%$ \\
\hline & \multicolumn{2}{|l|}{ Total } & $+6.29 \%$ & $+4.63 \%$ \\
\hline
\end{tabular}

Source: see Table 11.

As seen in Section 4, with the analysis that was made of Table 5, the government was the only institution with both current and total budget deficits (the group labelled as "others" within 
the group of households also recorded a current deficit, but without this having any significant repercussions on the total current balance of households).

The mathematical signs of the percentage changes, representative of the impacts occurring in both scenarios, continue, in almost all cases, to be equal, albeit with smaller values in scenario B.

Therefore, reflecting the situation defined in Table 11, in scenario A the budget balances of the institutions show a generalized decrease, except in the case of the current balance of those households that do not belong to the group of employees. The current balance of the general government was the one that suffered the greatest impact, with a reduction in the current deficit resulting mainly from the impact of the reduction in disposable income on final consumption. The impacts at the level of the capital balance were not significant - which was expected, because the experiment was conducted with the flows of the current account. In terms of the total balance, the net lending of households recorded a slight improvement $(0.38 \%)$, whereas that of financial corporations and non-profit institutions serving households worsened - the former significantly $(-14.74 \%)$ and the latter slightly $(-0.19 \%)$. In turn, the net lending of non-financial corporations was converted into net borrowing, although the net borrowing of the general government recorded a decrease of $2.97 \%$ - reflecting the decrease observed in the current deficit. All these fluctuations in the total budget balances resulted in an increase in the net borrowing of the economy of $6.29 \%$, as seen above.

Scenario B shows almost the same impacts, but with smaller values. In terms of the total budget balance, non-financial corporations maintain their net lending, although at a lower level, while the net borrowing of the general government records a slight decrease $(-0.36 \%)$ and the net lending of non-profit institutions serving households records a slight increase $(+0.18 \%)$. The final result is again an increase in the net borrowing of the economy $(4.63 \%)$, although not so significant as in scenario A.

Because the two experiments were performed using a version of the algebraic SAM with too many fixed parameters and exogenous variables, the structural changes were certainly not significant. Let us, however, look at the results.

Tables 6 and 7 showed that the compensation of labour received by employees represented $54.5 \%$, whereas the compensation of labour received by employers and/or own-account workers represented $7.5 \%$ and the compensation of capital represented $38 \%$ of generated income. From Table 13, a slight improvement can be seen in the positions of the latter two 
factors of production in detriment to the first - again with less significant impacts in scenario $\mathrm{B}$, as seen before. Workers with high and medium education levels were worse affected than workers with a low education level.

Table 13. Impacts (percentage change) on the distribution of gross added value, at factor cost, among factors of production of a reduction (of $1 \%$ ) in the direct tax rate paid by households to the government - scenario A - and of an increase (of 1\%) in social benefits other than social transfers in kind received by households from the government - scenario B.

\begin{tabular}{|c|c|c|c|c|}
\hline & Scenario A & Scenario B \\
\hline \multirow{4}{*}{\multicolumn{2}{|c|}{$\begin{array}{l}\text { Labour } \\
\text { - employees, with: }\end{array}$}} & low education level & $0.0 \%$ & $0.0 \%$ \\
\hline & & medium education level & $-0.9 \%$ & $-0.1 \%$ \\
\hline & & high education level & $-1.1 \%$ & $-0.1 \%$ \\
\hline & & Total & $-0.5 \%$ & $-0.1 \%$ \\
\hline \multirow{5}{*}{ Own assets } & \multirow{4}{*}{$\begin{array}{l}\text { Labour } \\
\text { - employers and/or } \\
\text { own-account } \\
\text { workers, with: }\end{array}$} & low education level & $+0.4 \%$ & $+0.1 \%$ \\
\hline & & medium education level & $+0.0 \%$ & $0.0 \%$ \\
\hline & & high education level & $-0.4 \%$ & $-0.1 \%$ \\
\hline & & Total & $+0.2 \%$ & $0.0 \%$ \\
\hline & \multicolumn{2}{|l|}{ Capital } & $+0,6 \%$ & $+0.1 \%$ \\
\hline
\end{tabular}

Source: see Table 11.

Table 8 showed that households received $84.5 \%$ of gross national income, with $62.1 \%$ corresponding to the group whose main source of income was wages and salaries (employees). Non-financial corporations received 16.4\%, with the remainder being distributed within the other institutions and with the general government recording a negative share. From Table 14, one can conclude that the two experiments generated scenarios in which the position of the institutions either did not change or registered a slight improvement - except, in scenario A, in the case of the households in general and of the group whose main source of income is wages and salaries (employees) in particular, and, in both scenarios, in the case of the general government, which recorded an increase in its negative position. 
Table 14. Impacts (percentage change) on the distribution of gross national income, at factor cost, among institutions and socioeconomic groups of a reduction (of $1 \%$ ) in the direct tax rate paid by households to the government - scenario $\mathrm{A}$ - and of an increase (of $1 \%$ ) in the social benefits other than social transfers in kind received by households from the government - scenario B.

\begin{tabular}{|l|l|r|r|}
\hline \multicolumn{2}{|l|}{} & Scenario A & Scenario B \\
\hline \multirow{3}{*}{$\begin{array}{l}\text { Group of households } \\
\text { (in accordance with the } \\
\text { main source of income) }\end{array}$} & $\begin{array}{l}\text { Employees } \\
\text { (including own account workers) }\end{array}$ & $-0.3 \%$ & $0.0 \%$ \\
\cline { 2 - 4 } & Recipients of pensions & $+0.4 \%$ & $0.1 \%$ \\
\cline { 2 - 4 } & Others & $+0.3 \%$ & $0.0 \%$ \\
\cline { 2 - 4 } & Total (households) & $-0.1 \%$ & $0.1 \%$ \\
\hline Non-financial corporations & $+0.6 \%$ & $+0.1 \%$ \\
\hline Financial corporations & $+0.6 \%$ & $+0.1 \%$ \\
\hline General government & $+0.6 \%$ & $+0.1 \%$ \\
\hline Non-profit institutions serving households & $+0.6 \%$ & $+0.1 \%$ \\
\hline
\end{tabular}

Source: see Table 11.

In turn, Table 9 showed that households had $69.3 \%$ of disposable income, with the group whose main source of income is wages and salaries (employees) having 41.9\%; the general government had a share of $16 \%$ (similar to the group of households whose main source of income is the compensation of labour received by employers, including own account workers) and the non-financial corporations had a share of $11.2 \%$, the others being less significant.

The scenarios that resulted from the two experiments undertaken represent the impacts shown in Table 15. In fact, once again, both scenarios reveal similar impacts, albeit less significant in the case of scenario B, which improved the relative positions of households, non-financial corporations and non-profit institutions serving households in detriment to the other two, with special emphasis being given to the case of the general government. Mention should also be made of the positive impact that was noted in the relative position of the group of households whose main source of income is connected with old age (recipients of pensions). 
Table 15. Impacts (percentage change) on the distribution of the disposable income of the institutions of a reduction (of $1 \%$ ) in the direct tax rate paid by households to the government - scenario $\mathrm{A}$ - and of an increase (of 1\%) in the social benefits other than social transfers in kind received by households from the government scenario B.

\begin{tabular}{|l|l|c|c|}
\hline \multicolumn{2}{|l|}{} & Scenario A & Scenario B \\
\hline \multirow{2}{*}{$\begin{array}{l}\text { Group of } \\
\text { households }\end{array}$} & Employees & $+1.20 \%$ & $+0.03 \%$ \\
\cline { 2 - 4 } $\begin{array}{l}\text { (in accordance } \\
\text { with the main } \\
\text { source of income) }\end{array}$ & Employers (including own account workers) & $+1.51 \%$ & $+0.11 \%$ \\
\cline { 2 - 4 } & Recipients of pensions & $+2.59 \%$ & $+0.92 \%$ \\
\cline { 2 - 4 } & Others & $+1.99 \%$ & $+0.26 \%$ \\
\hline non-financial corporations & $+1.48 \%$ & $+0.18 \%$ \\
\hline financial corporations & $+0.25 \%$ & $+0.02 \%$ \\
\hline general government & $-1.32 \%$ & $-0.17 \%$ \\
\hline non-profit institutions serving households & $-6.58 \%$ & $-0.79 \%$ \\
\hline
\end{tabular}

Source: see Table 11.

Thus, in this first approach to the question, the two experiments were conducted with the purpose of improving the financial situation of households; however, the scenarios that were generated show that not only did the situation of both households and the general government worsen, but so did the situation of the whole economy.

\section{Summary and concluding remarks}

This paper has presented numerical and algebraic versions of a SAM with an application to Portugal. In the former, each cell assumed a specific numerical value, with the sums of the rows being equal to the sums of the columns. In the latter version, each cell was represented by algebraic expressions that, together with those of all the other cells, represent a SAMbased model, the calibration of which involved a replication of the numerical version.

The underlying idea was that of Pyatt (1991) in the following text:

“... a SAM is a framework both for models of how the economy works as well as for data which monitor its workings. Recognition of this duality is of basic importance for quantitative analysis. It implies, inter alia, that the accounting identities which are captured by a SAM are not to be regarded simply as consistency requirements which must 
be imposed on a model, but rather they should be seen as a logical consequence of the paradigms which economists have adopted for analyzing society."

A study was undertaken at a macroeconomic level using the national accounts, within an ESA (95) framework, as the basic source of information.

Using the flexibility of the numerical version, through a top-down approach, additional sources were used to disaggregate the macro-SAM, with the RAS method having been used to adjust them to those of the basic source. In this way, therefore, the consistency of the whole system was not lost. This disaggregation was carried out by considering, on the one hand, the aim of studying the impacts of government policies on the distribution of income and, on the other hand, the data available for this purpose.

The definition of the algebraic version involved an identification of the national accounting transactions and their inclusion, with all possible details, in the characterising equations of each cell. This version should only be considered as a starting point and in the future the equations that have been defined will be tested and the parameters econometrically estimated, from time series of the national accounts transactions. Underlying paradigms should also be revised.

Macroeconomic aggregates and balances, as well as structural indicators of the distribution and use of income, were also calculated and formalised from both versions of the SAM, thereby providing an improved knowledge of the quantifiable side of the studied economy. A number of aspects were identified, such as the following:

- the government is the institution that has a total budget balance with a deficit (represented by its net borrowing), which is almost completely covered by the other institutions, with households having an important share, although this was, however, insufficient to avoid a net borrowing for the economy of 40 million euros ( $0.05 \%$ of GDP);

- current transfers from Portuguese institutions and net taxes on products are the main sources of receipts for the general government, whereas current transfers to Portuguese institutions and final consumption (a substantial part of this is transformed into transfers to households in kind) are its main items of expenditure;

- the income generated by households (or gross national income) and their final consumption are the main sources of receipts and expenditure, respectively;

- the compensation of labour received by employees represents $54.5 \%$ of generated income, whereas the compensation of labour received by employers and/or own-account workers represents $7.5 \%$ - a large proportion of these workers have a low education level; 
- the above-mentioned functional distribution of income also contributes with a share of $38 \%$ to the capital;

- households receive $84.5 \%$ of generated income and have $69.3 \%$ of disposable income; the group whose main source of income is wages and salaries (employees) is the most representative;

- final consumption absorbs the most significant part of the disposable income of institutions, except for the non-financial and financial corporations, even exceeding it in the case of the general government and of the group "others" amongst the households (those whose main source of income is not wages and salaries, mixed income including property income or income in connection with old age).

With the initial aim of improving the financial situation of households, two scenarios were defined and two experiments were performed in order to measure and identify impacts: a reduction of $1 \%$ in the direct tax rate paid by households to the government - scenario A; an increase of $1 \%$ in the social benefits other than social transfers in kind paid by the government to households - scenario B. Both of the impacts generated had similar mathematical signs, although the effects of scenario B were smaller. The direct effect of the two above-mentioned shocks on the (reduction of the) receipts of the general government had direct consequences for its final consumption, which, in turn, had obvious repercussions on both final demand and supply. The gross domestic product and gross national income (at market prices) then decreased, with consequences at the level of disposable income, consumption and saving (the current budget balance), as well as at the level of net lending/borrowing (the total budget balance). Particular emphasis is laid on the net borrowing of the economy, which increased by $6.29 \%$ in scenario A and by $4.63 \%$ in scenario B. Therefore, from the algebraic version of the SAM that was defined, the two experiments showed that the intention of improving the financial situation of households resulted in a worse overall situation, not only for the households themselves, but also for the economy in general and for all the other institutions, especially the general government.

Details were specified in order to provide the information needed not only to perform a similar exercise in other applications, but also to easily detect all the underlying failures, inconsistencies, errors, etc. The choice of experiments whose results can be compared with reality (which is not this case) is also very important. In the author's view, this is the way in which a work such as this one can be developed and improved upon. 
Modelling techniques can be considered as a support of (socio-)economic theory, so that better and more stable empirical evidence can help in the (re-)evaluation of this theory or even in the (re-)orientation of the way in which reality has traditionally been defined and conceptualised. The SAM, in both its versions, can be a valuable working instrument for these purposes.

At the same time, by using a working instrument such as the SAM, the design of policy can be based on a more positive and less normative analysis.

The potentialities and possibilities for further study provided by the SAM were emphasised, and, in this context, the author would like to encourage the authorities to include the teaching of its methodology in the curricula of courses in secondary and higher education, in the areas related with social sciences.

\section{References}

Dervis K. et al. (1982), General Equilibrium Models for Development Policy, Cambridge University Press, Cambridge (UK), 526 pp.

Drud A. et al. (1986), "Macroeconomic Modelling Based on Social Accounting Principles", Journal of Policy Modeling 8: 111-145.

Eurostat (1996), European System of Accounts (ESA 95). Eurostat, Luxembourg.

IWSG - Inter-Secretariat Working Group (1993), System of National Accounts (SNA 93). Commission of the European Communities - Eurostat, Brussels/Luxembourg; International Monetary Fund, Washington, DC; Organization for Economic Co-operation and Development, Paris; United Nations, Statistical Office, New York; World Bank, Washington DC.

LEG - Leadership Group on SAM (2003), "Handbook on Social Accounting Matrices and Labour Accounts", Eurostat Working Papers, Theme - Population and Social Conditions 3/2003/E/N 23, Luxembourg, 190 pp.

Pyatt G. (1988), “A SAM Approach to Modeling”, Journal of Policy Modeling 10: 327-352. 
Pyatt G. (1991), "Fundamentals of Social Accounting”, Economic Systems Research 3: 315341.

Pyatt G. and Roe A. (1977), Social Accounting for Development Planning with special reference to Sri Lanka, Cambridge University Press, Cambridge, 190 pp.

Pyatt G. and Round J. (1985), Accounting and Fixed Price Multipliers in a Social Accounting Matrix Framework, in Pyatt G. and Round, J. (eds.) Social Accounting Matrices. A Basis for Planning. A World Bank Symposium, The World Bank, Washington, DC 186-206; also in Economic Journal 89 (356): 850-873, 1979.

Round J. (2003), “Constructing SAMs for Development Policy Analysis: Lessons Learned and Challenges Ahead", Economic Systems Research 15: 161-183.

Santos S. (1999), “The Social Accounting Matrix as a working instrument for defining economic policy. Its application to Portugal during the period 1986-90, with emphasis on the agro-industrial sector", PhD dissertation, ISEG-TU Lisboa, Lisbon, 309 pp. (only available in Portuguese).

Santos S. (2001), "The importance of the Social Accounting Matrix. Its application to Portugal during the period 1990-95", ISEG-TU Lisboa - Seminar of the Department of Economics, Lisbon. 66 pp.

Santos S. (2003), "Quantitative analysis of the economic flows between Portugal and the other European Union Member States and Institutions in 1997”, Working Paper No. 2/2003, Centre of Research on European and International Economics - ISEG-TU Lisboa, Lisbon, 44 pp.

Santos S. (2003a), "Social Accounting Matrices for Portugal in 1998-99. Modelling the effects of changes in government receipts and expenditure", Working Paper No. 7/2003/ Department of Economics/Research Unit on Complexity and Economics - ISEG-TU Lisboa, Lisbon, 51 pp.

Santos S. (2004), "Portuguese net borrowing and the government budget balance. A SAM approach", Journal of Policy Modeling 26: 703-717. 
Santos S. (2004a), "Distribution of aggregate income in Portugal from 1995 to 2000 within a SAM framework. Modelling the household sector", Working Paper No. 12/2004/ Department of Economics/Research Unit on Complexity and Economics - ISEG-TU Lisboa, Lisbon, 33 pp.

Santos S. (2005), "Social Accounting Matrix and the System of National Accounts: An Application", Higher Institute of Economics and Business Administration. Working Paper No. 14/2005/ Department of Economics/Research Unit on Complexity and Economics ISEG-TU Lisboa, Lisbon, 41 pp.

Santos S. (2005a), "Effects of changes in flows of funds between Government and households. A SAM approach to Portugal”. EconWPA-GE (Working Paper Archive in Economics - General Equilibrium) 0507002, 40 pp.

Santos S. (2006), "Constructing a Database for Economic Modelling from the System of National Accounts: a Social Accounting Matrix for Portugal". Working Paper Series SSRN (Social Science Research Network) abstract=916089, 76 pp.

Santos S. (2007), "Modelling Economic Circuit Flows in a Social Accounting Matrix Framework. An Application to Portugal”. Applied Economics 39: 1753-1771.

Taylor L. and Arnim R. (2006), "Modelling the Impact of Trade Liberalisation. A Critique of Computable General Equilibrium Models", Oxfam International Research Report, New School for Social Research, New York, 61 pp. 
Appendix. Conventions and declarations

\section{Sets (set indices: lower-case subscripts)}

\section{f $\varepsilon$ Factors of production}

- Labour - employees (fle) [with low education level (flel), with medium education level (flem), with high education level (fleh)]

- Own assets (foa)

- Labour - employers and/or own-account workers (foal) [with low education level (foall), with medium education level (foalm), with high education level (foalh)]

- Capital - interests, profits, rents (foak)

a $\varepsilon$ Activities [agriculture, hunting and forestry; fishing and operation of fish hatcheries and fish farms (group1, a1); industry, including energy (group 2, a2); construction (group 3, a3); wholesale and retail trade, repair of motor vehicles and household goods, hotels and restaurants; transport and communications (group 4, a4); financial, real-estate, renting and business activities (group 5, a5); other service activities (group 6, a6)]

p $\varepsilon$ Products [products of agriculture, hunting, forestry, fisheries and aquaculture (group 1, p1); products from mining and quarrying, manufactured products and energy products (group 2, p2); construction work (group 3, p3); wholesale and retail trade services, repair services, hotel and restaurant services, transport and communication services (group 4, p4); financial intermediation services, real estate, renting and business services (group 5, p5); other services (group 6, p6)]

\section{di $\varepsilon$ Domestic Institutions}

- dic (current account of di) [households (dich): employees (group 1, dich1), employers and own account workers (group 2, dich2), recipients of pensions (group 3, dich3), others (group 4; dich4); non-financial corporations (dicnfe); financial corporations (dicfc); general government (dicg); non-profit institutions serving households (dicnpNPISHs)]

- dik (capital account of di) [households (dikh), non-financial corporations (diknfe), financial corporations (dikfe), general government (dikg), and non-profit institutions serving households (diknp-NPISHs)]

- dif (financial account of di) 


\section{rw $\varepsilon$ rest of the world}

In variables and parameters with two indices, the first represent the row and the second the column accounts (both indices may be equal).

\section{Parameters (lower-case, italics)}

$\alpha$.. $\quad$ share of the production of each group of activities in the value of production of each group of products

$\beta$.. $\quad$ proportion of gross added value in the value of production of each group of activities

$\gamma . \quad \quad$ proportion of intermediate consumption in the value of production of each group of activities

$a d v . . \quad$ share of the value of acquisitions less disposals of valuables of each group of products by each group of domestic institutions in the total value of acquisitions less disposals of valuables by these institutions

$a d v c . \quad \quad$ coefficient of acquisitions less disposals of valuables: amount expended by each group of domestic institutions on acquisitions less disposals of valuables per unit of gross saving

apc .. $\quad$ average propensity to consume of each group of domestic institutions: amount of final consumption per unit of (gross) disposable income

b2gp.. proportion of capital compensation (gross operating surplus) in labour compensation

b3s.. $\quad$ share of compensation of employers and/or own-account workers (gross mixed income) in the gross added value

ce.. coefficient of main source of income of domestic institutions (households) recipients of compensation of employees

$c g f c f$.. $\quad$ rate of coverage of gross fixed capital formation of each group of domestic institutions by investment grants received by these institutions

chinv.. $\quad$ share of the value of changes in inventories of each group of products by each group of domestic institutions in the total value of changes in inventories of that group of products

chinve.. coefficient of changes in inventories: amount of change in inventories of each group of products per unit of supply 
$\operatorname{clr} . \quad \quad$ share of compensation of employees paid by activities and sent to the rest of the world

coa.. coefficient of main source of income of domestic institutions (households) recipients of compensation of employers and/or own-account workers

$d l s . . \quad$ share of compensation of employees in the gross added value

$d 5 s . . \quad$ share of current tax on income, wealth, etc. paid by each group of domestic institutions to each group of domestic institutions (Portuguese general government), in the total of current tax on income, wealth, etc. paid by the former

d61s .. $\quad$ share of social contributions paid by each group of domestic institutions to each group of domestic institutions in the total of social contributions paid by the former

$d 62 s$.. $\quad$ share of social benefits other than social transfers in kind paid by each group of domestic institutions to each group of domestic institutions in the total of social benefits other than social transfers in kind paid by the former

d62rws.. share of social benefits other than social transfers in kind paid by each group of domestic institutions to the rest of the world in the total of social benefits other than social transfers in kind paid by the former

$d 7$.. $\quad$ share of other current transfers paid by each group of domestic institutions to each group of domestic institutions in the total of other current transfers paid by the former

$d 7 r w s$.. $\quad$ share of other current transfers paid by each group of domestic institutions to the rest of the world in the total of social benefits other than social transfers in kind paid by the former

$d 91$.. $\quad$ share of capital taxes paid by each group of domestic institutions (households) to each group of domestic institutions (Portuguese general government) in the total of capital taxes paid by the former

d92.. $\quad$ share of investment grants paid by each group of domestic institutions (Portuguese general government) to each group of domestic institutions in the total of investment grants received by the latter

d92rw. share of investment grants paid by the rest of the world to each group of domestic institutions in the total of investment grants received by the latter 
d99.. $\quad$ share of other capital transfers paid by each group of domestic institutions to each group of domestic institutions in the total of other capital transfers received by the latter

d99rw. $\quad$ share of other capital transfers paid by the rest of the world to each group of domestic institutions in the total of other capital transfers received by the latter

$f c s$.. $\quad$ proportion of expenditure on final consumption in each group of products in the total value of the final consumption of each group of domestic institutions

fcsrw .. $\quad$ proportion of expenditure on final consumption in the rest of the world in the total value of the final consumption of each group of domestic institutions

$g f c f$.. $\quad$ share of the value of gross fixed capital formation in each group of products by each group of domestic institutions in the total value of gross fixed capital formation by these institutions

icp.. $\quad$ coefficient of the intermediate consumption of products: proportion of intermediate consumption of each group of products per unit of intermediate consumption of each group of activities

ntag .. $\quad$ share of net taxes on production paid by each group of activities and received by domestic institutions (Portuguese general government)

ntarw .. $\quad$ share of net taxes on production paid by each group of activities and received by the rest of the world (European Union institutions)

ntpg.. $\quad$ share of net taxes on each group of products received by domestic institutions (Portuguese general government)

ntprw .. $\quad$ share of net taxes on each group of products received by the rest of the world (European Union institutions)

sc .. $\quad$ social contribution rate: social contributions paid by domestic institutions, per unit of received gross national income

si .. $\quad$ saving identity special

$s k . \quad \quad$ share of compensation of capital received by domestic institutions

ti .. direct tax rate: current taxes on income, wealth, etc. paid by domestic institutions, per unit of received aggregate income

$t k . \quad$ rate of capital tax levied on other capital transfers received by domestic institutions 
tm .. $\quad$ rate of trade and transport margins on each group of domestically transacted products: amount of trade and transport margins per unit of value of domestically transacted products

tmc .. $\quad$ trade and transport margins coefficient of correction

tp .. (net) tax rate on each group of products: amount of (net) taxes on products per unit of the value of domestically transacted products

\section{Exogenous variables (upper-case, at least the first letter, italics)}

CFR.. compensation of the factors of production received from the rest of the world

CFS.. compensation of the factors of production sent to the rest of the world

$D 1 R W$.. compensation of employees (transaction D1 of the National Accounts) received from the rest of the world

$D 4 P R W$.. $\quad$ property income (transaction D4 of the National Accounts) sent to the rest of the world

$D 4 R W$.. $\quad$ property income (transaction D4 of the National Accounts) received from the rest of the world

D62P .. $\quad$ social benefits other than social transfers in kind (transaction D62 of the National Accounts) paid by domestic institutions

$D 62 R W$.. $\quad$ social benefits other than social transfers in kind (transaction D62 of the National Accounts) received by domestic institutions from the rest of the world

D7P .. $\quad$ other current transfers (transaction D7 of the National Accounts) paid by domestic institutions

$D 7 R W$.. $\quad$ other current transfers (transaction D7 of the National Accounts) received by domestic institutions from the rest of the world

D8 .. $\quad$ adjustment made for the change in the net equity of households in pension fund reserves (transaction D8 of the National Accounts)

D92P .. $\quad$ investment grants (transaction D92 of the National Accounts) paid by domestic institutions (Portuguese general government) to the rest of the world

D99P .. $\quad$ other capital transfers (transaction D99 of the National Accounts) paid by domestic institutions to the rest of the world

D99R .. other capital transfers (transaction D99 of the National Accounts) received by domestic institutions 
EX.. $\quad$ value of exports (transaction P6 of the National Accounts, at f.o.b. prices)

FT .. $\quad$ financial transactions (transactions F1 to F7 of the National Accounts), except those received from the rest of the world

$I M$.. $\quad$ value of imports (transaction P7 of the National Accounts, at c.i.f. prices)

K2 .. $\quad$ acquisitions less disposals of non-financial non-produced assets (transaction K2 of the National Accounts)

NTAA .. net taxes on production paid by each group of activities

P51 .. $\quad$ value of gross fixed capital formation (transaction P51 of the National Accounts)

\section{Endogenous variables (upper-case, at least the first letter, normal)}

AD .. $\quad$ value of aggregate demand (at market prices)

AFIP .. $\quad$ aggregate factors income (paid)

AFIR .. aggregate factors income (received)

AI .. $\quad$ aggregate income (received)

AINV .. aggregate investment

AIP .. $\quad$ aggregate income (paid)

AS .. $\quad$ aggregate supply (value at market prices)

B2g.. $\quad$ gross operating surplus (balance B2g of the National Accounts)

B3g .. $\quad$ gross mixed income (balance B3g of the National Accounts)

CFS.. compensation of the factors of production sent to the rest of the world (except, property income sent to the rest of the world)

CT .. $\quad$ current transfers

CTP .. (total) current transfers paid by each group of domestic institutions to (all) domestic institutions

CTR .. (total) current transfers received by each group of domestic institutions from (all) domestic institutions

DI .. $\quad$ (gross) disposable income

Didi .. percentage of gross disposable income received by domestic institutions

Digav .. $\quad$ percentage of income generated by the factors production

Digavfle .. percentage of income generated by employees, by level of education

Digavfoal .. percentage of income generated by employers and/or own-account workers, by level of education 
Digavfoak ..indicator of the distribution of income (gross added value) generated by capital among activities (in percentage terms)

Digni.. percentage of generated income (gross national income) received by domestic institutions

DT.. $\quad$ value of domestically transacted products, at basic-c.i.f. prices

DTmp .. $\quad$ value of domestically transacted products, at market prices

D1 .. $\quad$ compensation of employees (transaction D1 of the National Accounts)

D5 .. $\quad$ current taxes on income, wealth, etc. (transaction D5 of the National Accounts)

D61 .. $\quad$ social contributions (transaction D61 of the National Accounts)

D91P.. capital taxes (transaction D91 of the National Accounts) paid by domestic institutions

D92R .. investment grants (transaction D92 of the National Accounts) received by domestic institutions

E .. $\quad$ employed population

FC .. $\quad$ value of final consumption (transaction P3 of the National Accounts), at market prices

FTRW .. financial transactions (transactions F1 to F7 of the National Accounts) received by domestic institutions from the rest of the world

GAV .. gross added value, at factor cost

GCF .. value of gross capital formation (transaction P5 of the National Accounts), at market prices

GDP.. gross domestic product, at market prices

GNI .. gross national income, at factor cost

GNIMP.. gross national income, at market prices

INVF .. $\quad$ investment funds

KT .. capital transfers

KTP .. (total) capital transfers paid by each group of domestic institutions to (all) domestic institutions

KTR .. (total) capital transfers received by each group of domestic institutions from (all) domestic institutions

NLB .. $\quad$ net lending / borrowing

NTA .. $\quad$ net taxes on production (transaction D29-D39 of the National Accounts) 
NTP .. $\quad$ net taxes on products (transaction D21-D31 of the National Accounts)

P52 .. value of changes in inventories (transaction P52 of the National Accounts)

P53 .. value of acquisitions less disposals of valuables (transaction P53 of the National Accounts)

S.. $\quad$ gross saving

TFTP .. $\quad$ total financial transactions (paid)

TFTR .. $\quad$ total financial transactions (received)

TM .. $\quad$ trade and transport margins (without correction)

TMc .. trade and transport margins - correction

TMT .. $\quad$ trade and transport margins with correction

TVRWP .. value of transactions to the rest of the world

TVRWR .. transactions value from the rest of the world

UdiFC .. percentage of gross disposable income used in final consumption by domestic institutions

UdiS .. $\quad$ percentage of gross disposable income used in (gross) saving by domestic institutions

VCT .. $\quad$ value of total costs (at basic prices)

VIC .. value of intermediate consumption (transaction P2 of the National Accounts) at market prices

VP .. $\quad$ value of production (transaction P1 of the National Accounts), at basic prices

VPT.. $\quad$ total production value (at basic prices) 